\title{
Impact of microzooplankton on the progression and fate of the spring bloom in fjords of northern Norway
}

\author{
Stephen D. Archer ${ }^{1, *}$, Peter G. Verity ${ }^{2}$, Jacqueline Stefels ${ }^{3}$ \\ ${ }^{1}$ Plymouth Marine Laboratory, Prospect Place, Plymouth PL1 3DH, United Kingdom \\ ${ }^{2}$ Skidaway Institute of Oceanography, 10 Ocean Science Circle, Savannah, Georgia 31411, USA \\ ${ }^{3}$ Department of Marine Biology, University of Groningen, PO Box 14, 9750 AA Haren, The Netherlands
}

\begin{abstract}
The objective of the study was to determine the role of microzooplankton in the fate of primary production and progression of the spring phytoplankton bloom in high latitude fjords. The 3 fjords, Balsfjord, Malangen and Ullsfjord (Norway), varied in oceanic influence and in the rate of development of the spring bloom. The abundance of Phaeocystis pouchetii was relatively low in the spring of 1997 compared to previous years, and diatoms dominated the biomass of the phytoplankton assemblage in all 3 fjords. The mean biomass of microzooplankton in the top $20 \mathrm{~m}$ averaged 72, 66 and $80 \mathrm{mg} \mathrm{C} \mathrm{m}^{-3}$ and values integrated to $170 \mathrm{~m}$ averaged 4560,4450 and $6820 \mathrm{mg} \mathrm{C} \mathrm{m}^{-2}$ in Balsfjord, Malangen and Ullsfjord, respectively. The composition of the microzooplankton was consistent among the fjords and over time, with the proportion of biomass split evenly between nanoflagellates, dinoflagellates and ciliates. Grazing rates of the microzooplankton community were measured with the dilution technique. The impact of microzooplankton grazing was similar among the fjords, accounting for on average 68,63 and $55 \%$ of the production of the $<200 \mu \mathrm{m}$ phytoplankton in Balsfjord, Malangen and Ullsfjord, respectively. When integrated to $20 \mathrm{~m}$, based on a microzooplankton biomass-specific ingestion rate, microzooplankton grazing accounted for an estimated 12 to $26 \%$ of the gross primary production. However, this does not account for the carbon requirements of a substantial proportion of the microzooplankton that occurred below $20 \mathrm{~m}$. Clearance rates by ciliates of nanophytoplankton cells of a similar size to the single cells of $P$. pouchetii were determined from the uptake rates of fluorescently labelled algae (FLA). Generally, the taxa of ciliates that were found to ingest FLA accounted for $\geq 50 \%$ of the abundance of the ciliate population in each fjord. Taxon-specific ciliate clearance rates of FLA in surface waters varied with ciliate size from 5.6 to $1.3 \mu \mathrm{cell}^{-1} \mathrm{~h}^{-1}$. The FLA-consuming ciliate population cleared a total of $27 \times 10^{3}$ to $141 \times 10^{3} \mathrm{\mu l} \mathrm{l}^{-1} \mathrm{~d}^{-1}$ in surface waters. The ingestion rates of the FLA-consuming ciliates were equivalent to between 11 and $29 \%$ of the total microzooplankton consumption. It is possible that the grazing pressure exerted by the microzooplankton on single cells and small colonies was high enough to decrease the overall competitiveness of the $P$. pouchetii populations and contribute to their low abundance.
\end{abstract}

KEY WORDS: Plankton · Grazing $\cdot$ Spring bloom $\cdot$ Norwegian fjords Resale or republication not permitted without written consent of the publisher

\section{INTRODUCTION}

The spring phytoplankton bloom in fjordic environments is the most important period of carbon flux during the year, with high new production, biomass accumulation and often high sedimentation rates (Wassmann

*E-mail: stda@ccms.ac.uk
1991). In the sub-arctic fjords of northern Norway, spring blooms generally happen from late March to late April and are responsible for approximately 50\% of the annual production (e.g. Eilertsen \& Taasen 1984). The 'classical' view of spring blooms at high latitudes is that they are dominated by relatively large phytoplankton that support short food chains with low levels of recycling and efficient transfer of production to higher trophic levels, including fisheries (Cushing 1989, 
Legendre \& Le Fèvre 1989, Legendre 1990). The fjords of northern Norway are closely connected to the water masses of the continental shelf and are an integral part of the open coastal zone and shelf seas that support the recruitment of major stocks of fish including herring, capelin and cod.

A Phaeocystis pouchetii-Chaetoceros socialis-Nitzschia grunowii spring phytoplankton assemblage commonly occurs in north Norwegian fjords (Eilertsen et al. 1981a). However, the relative abundance of taxa can show considerable interannual variability, with implications for the fate of primary production (Eilertsen et al. 1981a, Eilertsen \& Taasen 1984). Resource- versus predator-based competition is thought to account for these variations (Verity \& Smetacek 1996, Lancelot et al. 1998). Calanus finmarchicus and Metridia longa are the most important herbivorous mesozooplankton grazers in north Norwegian fjords. Both species spawn in April (Tande 1982, Tande \& Grønvik 1983) and their nauplii start to feed towards the end of April, too late to take advantage of the major period of the spring bloom (Eilertsen \& Taasen 1984). However, the bloom may be grazed by overwintering or migrating populations of copepods and euphausiids (e.g. Hopkins et al. 1984, Norrbin 1994). The sedimentation of carbon in the form of fecal pellets is generally high compared to ungrazed phytoplankton at this time, which is evidence of significant zooplankton herbivory (e.g. Riebesell et al. 1995, Keck \& Wassmann 1996, Reigstad \& Wassmann 1996). Similarly, polyunsaturated fatty acids, most likely originating from $P$. pouchetii, were found in several zooplankton taxa from these fjords, suggesting active grazing on the colonial form of $P$. pouchetii (Sargent et al. 1985).

Few studies have examined the contribution of small phytoplankton to primary production or addressed the fate of that production in north Norwegian fjords. Photosynthetic nanoplankton, including the solitary cells of Phaeocystis pouchetii are an abundant component of the spring assemblage (Eilertsen et al. 1981a). In contrast to the colonial phase, the flagellate stage of Phaeocystis is thought to support a community based on a microbial food web, with regeneration of nutrients and carbon in surface waters (Weisse et al. 1994, Lancelot et al. 1998). Grazing by microzooplankton, particularly ciliates, may control the single cell phase of Phaeocystis (Weisse \& Scheffel-Möser 1990, Hansen et al. 1993) and thereby affect the development and competitiveness of the colonial form during the spring bloom. Small-celled phytoplankton and nano/microzooplankton were found to dominate the waters of 2 west Norwegian fjords in late spring (Verity \& Vernet 1992) and the surface waters of the north Norwegian shelf from March to October (Verity et al. 1999). In both cases, the microbial food web was responsible for much of the production and consumption of particulate organic matter in the euphotic zone. Microzooplankton are also important because they act as a food source for meso/macrozooplankton, channeling energy and nutrients from the microbial loop to higher trophic levels (reviewed in Stoecker \& Capuzzo 1990, Gifford 1991).

The objective of the present study was to determine the role of microzooplankton in the fate of primary productivity and progression of the spring phytoplankton bloom in high latitude fjords where $P$. pouchetii is a dominant feature. To do this we examined the taxonomic composition, abundance and biomass of microzooplankton communities in 3 fjords and used a combination of approaches to quantify their impact on primary production and food web structure. The study reported here is part of the ESCAPE (Entangled Sulfur and CArbon cycles in Phaeocystis pouchetii-dominated Ecosystems) programme, carried out in northern Norway in 1997 (Stefels 1997).

\section{METHODS}

Research strategy. Visits to 3 fjords were conducted during April 1997 aboard the RV 'Johan Ruud'. Balsfjord, Malangen, and Ullsfjord (Fig. 1) were visited in succession approximately every third day between the 8 and 25 April. Balsfjord is a $57 \mathrm{~km}$ long, narrow fjord with 3 connections to the shelf, the $35 \mathrm{~m}$ sill separating

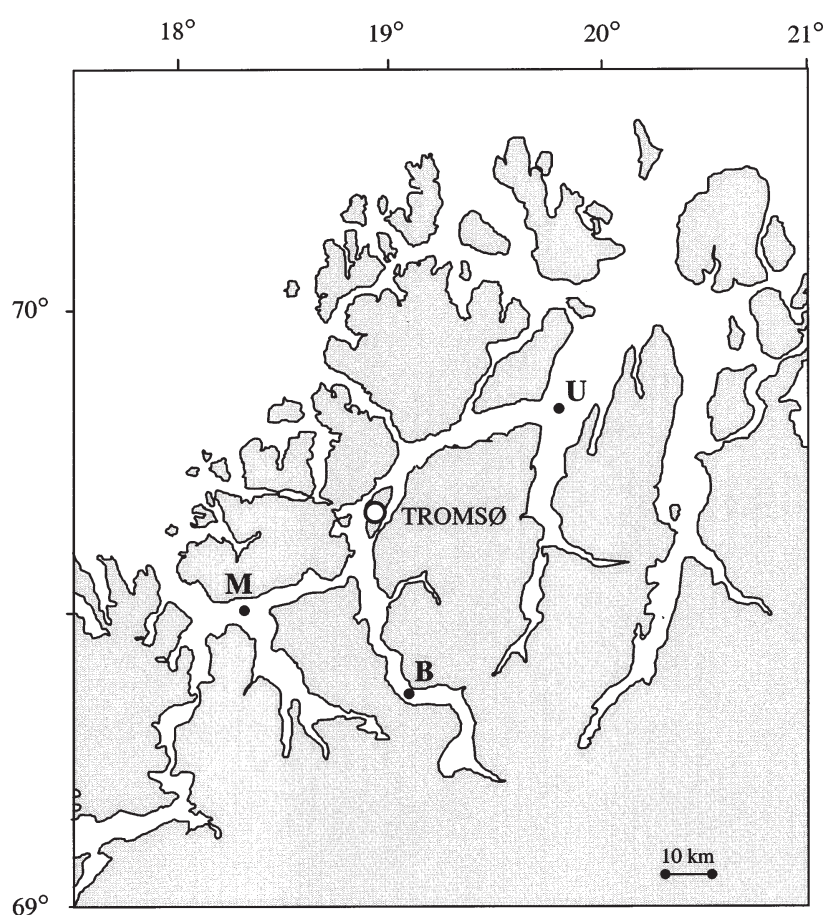

Fig. 1. The investigation area surrounding the city of Tromsø in northern Norway with the location of sampling sites (•) in the 3 fjords, Balsfjord (B), Malangen (M) and Ullsfjord (U) 
it from Malangen being the most important. Malangen is connected to coastal waters by a narrow but deep $(\sim 240 \mathrm{~m})$ sill, and sampling took place in the outer of the 2 basins in the $60 \mathrm{~km}$ long fjord. Of the 3 fjords, the $70 \mathrm{~km}$ long Ullsfjord is the most open to coastal waters, with a wide entrance and $170 \mathrm{~m}$ deep sill.

Our objectives were to combine frequent estimates of herbivory by microzooplankton with vertical profiles of plankton biomass and information on the composition of grazer communities. The plankton biomass data reported here reflect the dawn samplings at up to 9 depths from the surface to $170 \mathrm{~m}$. Each day after the dawn profile, 501 of surface water was collected with an acid-cleaned water bottle and stored in 2 cleaned carboys, for use in dilution experiments. Additional surface water was collected and stored briefly in carboys during transit (ca 1 h) to the University of Tromsø, where samples were prepared to determine concentrations of chlorophyll a (chl a) and the composition, abundance, biomass, and grazing rates of planktonic ciliates. These measurements and experiments could not be performed aboard ship because of space limitations.

Characterisation of the microbial community. Chl a: Subsamples (1 to 4 l) collected from each depth of the dawn cast were filtered over Whatman GF/F filters, wrapped in aluminium foil, quickly frozen in liquid nitrogen and stored at $-80^{\circ} \mathrm{C}$. After freeze-drying the filter, pigments were extracted in $90 \%$ acetone in the dark for $>12 \mathrm{~h}$ at $4^{\circ} \mathrm{C}$. Pigments were analysed by HPLC on a Pharmacia-LKB liquid chromatograph.

Abundance and biomass of autotrophs: Samples $(250 \mathrm{ml})$ from surface water collected at dawn were fixed with a modified Lugol's solution (Rousseau et al. 1990). After sedimentation, cells were counted with an inverted microscope (Olympus IMT-2). The biovolumes of each taxon were computed from the form and size of cells using specially developed software. For diatoms an approximation of the biovolume was calculated by assuming a mean plasma layer of $1 \mu \mathrm{m}$ between the cell membrane and the vacuole (Edler 1979), giving a mean biovolume of $30 \%$ of the total cell volume. The carbon content of autotrophs was calculated from cell biovolume according to the conversion factors of Edler (1979).

Abundance and biomass of heterotrophs: Numerically abundant heterotrophic protozoa $<200 \mu \mathrm{m}$, including ciliates, aplastidic flagellates and dinoflagellates (the microzooplankton), were enumerated in samples from $0,4,8,12,20,40,60,100$, and $170 \mathrm{~m}$. Bacteria were enumerated in samples from $0,20,40,60$, and $100 \mathrm{~m}$. Subsamples for microzooplankton were preserved in glutaraldehyde (final concentration $=0.3 \%$ ) and then stained with 3-6-diaminoacridine hemisulfate (proflavin) for $1 \mathrm{~min}$ ( $5 \mu \mathrm{g} \mathrm{ml}^{-1}$ final concentration) and 4'6-diamindino-2-phenylindole (DAPI) for $4 \mathrm{~min}$ (5 $\mu \mathrm{g}$ $\mathrm{ml}^{-1}$ final concentration). Samples for bacteria were stained only with DAPI. Separate volumes were then filtered onto 0.2 and $0.8 \mu \mathrm{m}$ black Nuclepore filters: bacteria were measured on the smaller pore-size filters, and microzooplankton on the larger filters. To achieve an even distribution for counting and measurement purposes, black filters were placed on top of pre-wetted Whatman GF/F backing filters. After filtration, the damp filter was placed on a slide. A drop of low fluorescence immersion oil was placed on top of the filter, which was covered with a cover slip and frozen at $-20^{\circ} \mathrm{C}$. Samples were analyzed upon return to the laboratory.

An Olympus BX-60 microscope equipped with $100 \mathrm{~W}$ epifluorescence illuminators was employed, with appropriate exciter/barrier filter sets for UV (335 to $365 \mathrm{~nm}$ ), blue (435 to $490 \mathrm{~nm}$ ), and green (510 to $560 \mathrm{~nm}$ ) excitation. Dinoflagellates were distinguished from other flagellates based upon cell morphology and structure of the nucleus, especially the unique condensed chromosomes visible by DAPI staining. Heterotrophic and autotrophic cells were discriminated by the absence and presence of autofluorescent chloroplasts, respectively. The autotrophic category also includes mixotrophic cells. Cell abundance, dimensions, and biovolumes were determined via quasi-automated color image analysis (Verity \& Sieracki 1993) equipped with a Photonics Science cooled integrating 3-chip color CCD with variable frame rates from $1 / 10000 \mathrm{~s}$ to $4 \mathrm{~min}$ and an electronic shutter mounted in-line in the microscope lightpath so that the sample was exposed to excitation for only as long as the camera shutter was open. The computer could automatically select random locations on the slide and return to each location $\pm 1 \mu \mathrm{m}$. The commercial driver software (Image Pro Plus v3.0) was customised so that the entire process (focusing, opening an electronic shutter, grabbing an image, closing the shutter, and moving to a new location) was automated and computer-controlled.

A minimum of 200 plankton cells of each type and 20 image fields of bacteria (typically 1000 cells) were measured. The average coefficient of variation of triplicate counts of bacteria and nanoplankton was 8 and $11 \%$, respectively. Data were automatically transferred to spreadsheets, and every cell in an image was uniquely identified for post-measurement visual confirmation. Cell biovolume measurements were converted to carbon biomass using conversion factors based on literature values of the carbon density of bacteria (Kroer 1994) and nano- and microplankton (Verity et al. 1992).

Primary production. Net primary production (NPP) was determined from $\mathrm{TCO}_{2}$ analyses in incubated samples. From the dawn cast, samples from the top 5 depths were directly poured into oxygen bottles and incubated in an on-deck incubator that was kept at in situ temperature for $24 \mathrm{~h}$. Duplicate samples were stored in $5 \mathrm{incu-}$ 
bator tubes with different light levels: light was attenuated with blue-light sheets at 54, 30, 14, 6.3 and $2.4 \%$ of the incoming light. Community respiration (DCR) was measured in samples placed in the dark. After incubation, the samples were fixed with mercuric chloride and stored cool until analysis in the laboratory. Time-zero concentrations were taken from the $\mathrm{TCO}_{2}$ profile measurements. $\mathrm{TCO}_{2}$ was analysed within $36 \mathrm{~h}$ by coulometry (Stoll et al. 1993). NPP was calculated by subtracting the $\mathrm{TCO}_{2}$ of the incubated bottles from the time-zero values. Gross primary production (GPP) was calculated from the combination of NPP and DCR. In order to calculate the total water column primary production, daily attenuation of light over the water column was measured with a spherical quantum sensor.

Determination of herbivory. A dilution approach was used to determine the rates of herbivory by the microzooplankton community, and fluorescently labeled algae (FLA) were used as tracers of the clearance rates of nanophytoplankton cells by ciliates.

Dilution protocol: Surface water was apportioned into 2 carboys for use as dilution water and experimental water. All equipment which came into contact with seawater (e.g. carboys, tubing, filtration equipment, and meshes) was stored in dilute acid between uses and rinsed with deionized water immediately prior to use. Dilution water was prepared by gravity filtration directly from carboys through sequential 3.0 and $0.2 \mu \mathrm{m}$ Gelman capsule filters into 251 polyethylene carboys. This process removed all phytoplankton, including the smallest picoplankton, which has been shown previously (Verity et al. 1996) and was confirmed here by pigment fluorometry. Most bacteria were also retained except very small vibrios. The capsule filters were soaked in $10 \% \mathrm{HCl}$ for $1 \mathrm{~d}$ before initial use and in between uses. Prior to each use, ca $10 \mathrm{l}$ of seawater were passed through them to remove any traces of acid. Post-cruise nutrient analyses showed that the concentrations of ammonium, nitrate+nitrite, silicate, and phosphate were the same in seawater before and after capsule filtration, as previously shown in more oligotrophic waters (Verity et al. 1996). Cartridges were changed after every 3 experiments.

Concurrently, experimental water was gently sieved through a $200 \mu \mathrm{m}$ Nitex mesh into a separate acidcleaned polyethylene carboy. Two litre Teflon bottles served as incubation vessels. Experimental water was gently added to dilution water to create 5 duplicated dilution treatments in $20 \%$ increments. Dissolved inorganic nitrogen and silicate concentrations were typically 1 to $3 \mu \mathrm{M}$ and phosphate was 0.3 to $0.5 \mu \mathrm{M}$ (P.G.V. unpubl. data), as expected for this time of year (Hegseth et al. 1995). Low concentrations of macronutrients $\left(\mathrm{NO}_{3}: \mathrm{Si}: \mathrm{PO}_{4}=5: 5: 0.5 \mu \mathrm{M}\right)$ were added during the experiments to minimize potential nutrient limita- tion; however, nutrients did not decrease significantly during the experiments (P.G.V. unpubl. data). Bottles were incubated in flowing seawater in deck incubators covered with 1 layer of neutral density screening to match near-surface irradiance. Incubations typically began at 09:00 h local time; at $T_{0}$ and $T_{24}$ hours, samples were collected to measure chl a from all dilutions. Samples for chl a were collected in duplicate on Gelman GF/F filters, stored frozen in the dark, and measured fluorometrically after dark extraction into cold $90 \%$ acetone using a Turner Designs fluorometer (Strickland \& Parsons 1972). Calibration factors were determined and checked at regular intervals using pigments derived from phytoplankton cultures and measured using HPLC. The range in coefficients of variation for chl a was 3 to $5 \%$.

Phytoplankton growth rates and grazing by microzooplankton were estimated as described by Landry \& Hassett (1982) and Landry (1993). Deviations from linearity in the relationship between apparent growth rate and dilution (Gifford 1988, Gallegos 1989) were not apparent in these experiments, similar to observations in other Norwegian fjords (Verity \& Vernet 1992) and in the adjacent Barents Sea (P.G.V. et al. unpubl.).

FLA experimental protocol: Heat killed FLA were prepared from a clonal culture of Chlorella stigmatophora (PCC 85) to act as analogues of nanophytoplankton, in particular the solitary cells of Phaeocystis pouchetii. Cells were stained with 5-([4,6-dichlorotriazin-2-yl]amino) fluorescein (DTAF) (Sigma) (Sherr et al. 1987, Rublee \& Gallegos 1989) and stored in $1 \mathrm{ml}$ aliquots at $-20^{\circ} \mathrm{C}$ in pyrophosphate buffer solution. Prior to use, thawed aliquots were examined to check that the FLA had not formed clumps and that their fluorescence was sufficiently bright. The mean diameter of the FLA after thawing was $4.8 \pm 0.6$ (SD) $\mu \mathrm{m}$.

Water samples were collected from near the surface at dawn and transported to the laboratory in a 501 acidcleaned carboy. FLA incubations were carried out at simulated in situ temperatures and light levels in a temperature controlled room in the laboratory. The incubations were conducted in triplicate in $1.11 \mathrm{Nal}-$ gene ${ }^{\circledR}$ polycarbonate bottles. Experimental water was gently siphoned into the incubation bottles by 11:30 h. FLA were added approximately $1 \mathrm{~h}$ after the water had been added to the incubation bottles to allow the grazers to recover from any handling shock. FLA were added to produce a final concentration of approximately $1000 \mathrm{FLA} \mathrm{ml}^{-1}$. The bottles were gently rotated for $1 \mathrm{~min}$ and $125 \mathrm{ml}$ subsampled at 0 and approximately 10, 20, and $30 \mathrm{~min}$ and immediately fixed in acid Lugol's at a final concentration of $0.4 \%$. Samples were stored in the dark in glass bottles.

The concentration of FLA at the start of each incubation was determined by flow cytometric analysis of acid 
Lugol's fixed samples, cleared with a few drops of $5 \%$ $(\mathrm{w} / \mathrm{v})$ sodium thiosulphate. Counts were performed with a FAC-Sort flow cytometer (Becton Dickinson, Oxford, UK) equipped with a $15 \mathrm{~mW}$ laser exciting at $488 \mathrm{nM}$ and a standard filter setup. Parameters were collected as logarithmic signals and graphs drawn and analysed using the WinMDI free software (Joseph Trotter, The Scripps Research Institute [facs.scripps.edu]). A combination of $90^{\circ}$ light scatter and green fluorescence was used to distinguish FLA from other particles.

Settled aliquots $(50 \mathrm{ml})$ of the fixed subsamples were analysed using epifluorescence inverted microscopy (Leica DM IRB, with an I3 filter cube [BP 450-490 excitation filter]) to determine the average number of FLA per ciliate at each time point. Prior to settling, a few drops of a $5 \%(\mathrm{w} / \mathrm{v})$ sodium thiosulphate solution were added to clear the samples. FLA uptake rates were calculated via linear regression analysis to provide per-cell clearance rates. Per-cell clearance rates were multiplied by the empirically derived abundance to provide clearance rates of the total ciliate population and taxon-specific assemblages. The taxonomy, abundance and biovolume of ciliates were determined in the water used for FLA experiments. Ciliates were characterised and enumerated in the same settled samples used to determine FLA uptake rates. Ciliates were identified from cells fixed in acid Lugol's, and their taxonomy was based on the morphological details described by Montagnes \& Lynn (1991). The biovolume of ciliates was determined in acid Lugol's fixed samples using an image analysis system. Cell area and maximum length were used to calculate cell volume assuming appropriate geometric shapes. The biomass of ciliates was calculated from the biovolume using literature values (Verity et al. 1992). from 1.6 to $2.4,3.0$ to 4.1 and 3.6 to $4.0^{\circ} \mathrm{C}$ in Balsfjord, Malangen, and Ullsfjord, respectively. Salinities were 33.59 to $33.80,33.76$ to 34.35 , and 34.04 to 34.49 PSU in Balsfjord, Malangen, and Ullsfjord, respectively. Densities ranged from 26.86 to $26.98,26.90$ to 27.26 , and 27.07 to $27.39 \mathrm{~kg} \mathrm{~m}^{-3}$ in Balsfjord, Malangen and Ullsfjord, respectively. Inflow events of more saline water were not detected in Malangen or Balsfjord in the first 2 wk of the study but some inflow was evident in Ullsfjord by 25 April. The onset of the spring bloom is considered to be largely a consequence of increasing irradiance (Eilertsen et al. 1981a). The winter of 1997 was one of near-record snowfall, and snow continued to fall throughout the study period. Despite this, during the $2 \frac{1}{2}$ wk of study, levels of solar irradiance and air temperature rose gradually except for several days of inclement weather on 16 to 18 April (Fig. 2).

\section{Community composition and primary production}

\section{Phytoplankton}

The pattern of progression of the 'spring bloom' varied between the fjords. Chl a concentrations at the beginning of the study were similar in all 3 fjords and ranged from 5.4 to $6.3 \mathrm{mg} \mathrm{m}^{-3}$ in surface waters. They reached highest levels in Balsfjord, increasing from $6 \mathrm{mg} \mathrm{m}^{-3}$ on April 8 to $11 \mathrm{mg} \mathrm{m}^{-3}$ on 17 April (Fig. 3). Integrated concentrations increased from $252 \mathrm{mg} \mathrm{m}^{-2}$ on 8 April to $540 \mathrm{mg} \mathrm{m}^{-2}$ by 17 April (Table 1). In contrast, in Malangen, near-surface chl a concentrations

\section{RESULTS}

Three fjords were sampled in order to maximise the likelihood of observing different portions of plankton community development during a relatively brief window in time. In order of increasing oceanic influence, the basins sampled in Balsfjord, Malangen, and Ullsfjord were 180, 220, and $270 \mathrm{~m}$ deep, respectively. All 3 have been described and studied previously, especially Balsfjord (e.g. Skjoldal et al. 1995, Wassmann et al. 1996 and citations therein). The fjords remain ice free throughout the year with minimum temperatures in the surface waters of close to $1^{\circ} \mathrm{C}$ in February and March (e.g. Eilertsen et al. 1981b). As is usual in April, all 3 fjords exhibited only slight stratification, primarily in the upper 50 to $100 \mathrm{~m}$. Water temperatures ranged

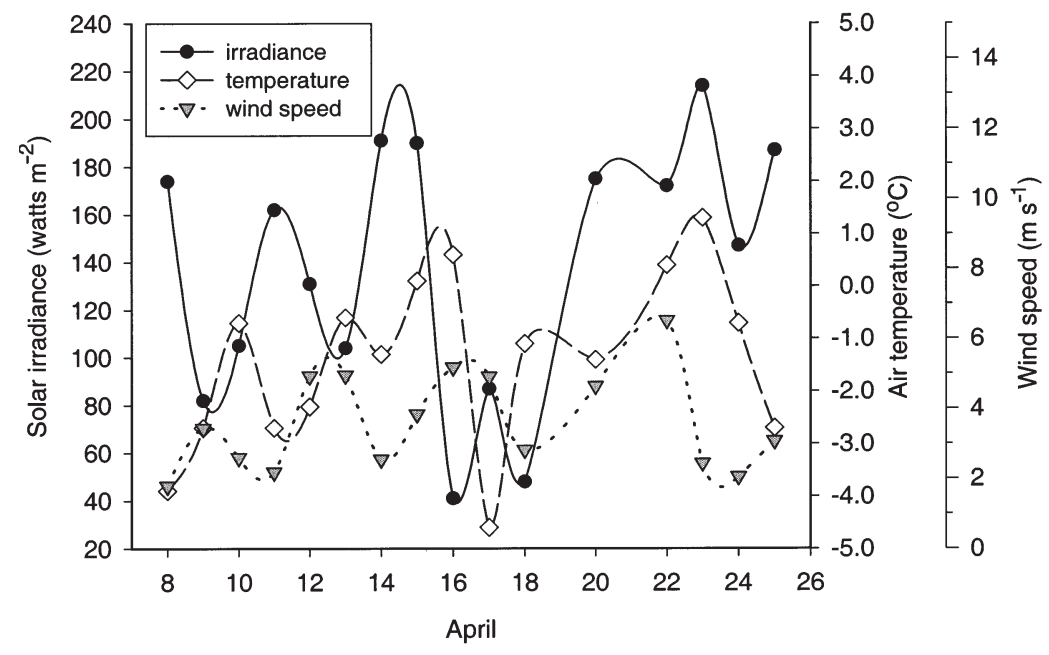

Fig. 2. Meteorological data recorded at the University of Tromsø during the period of the study. The values are means of measurements measured throughout the day at $1 / 2$ min intervals. Data obtained from the Storm Cast project, University of Tromsø 

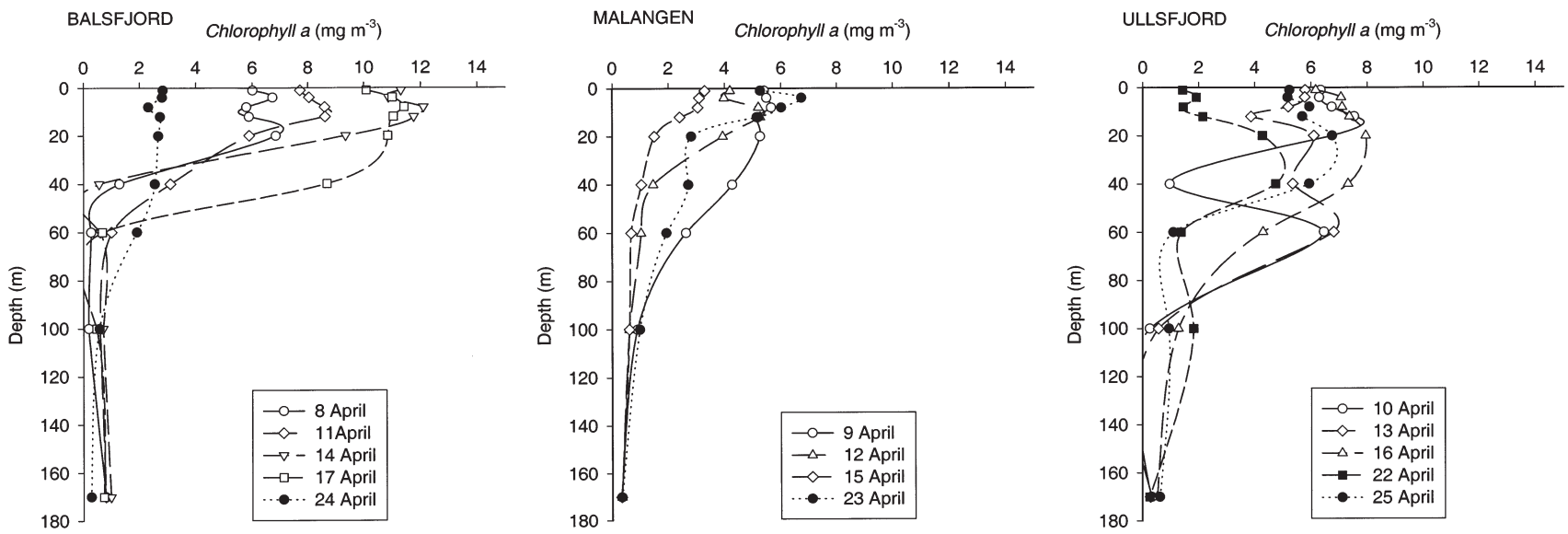

Fig. 3. Temporal changes in the depth profiles of total chl a recorded at each fjord during April 1997

decreased from $5.5 \mathrm{mg} \mathrm{m}^{-3}$ on 9 April to $3.0 \mathrm{mg} \mathrm{m}^{-3}$ by 15 April (Fig. 3). Integrated values also decreased, reaching a minimum of $110 \mathrm{mg} \mathrm{m}^{-2}$ on 15 April. In Ullsfjord, chl a concentrations remained relatively constant in surface waters prior to 16 April (Fig. 3), with higher levels at greater depth accounting for the high integrated values of 426 to $499 \mathrm{mg} \mathrm{m}^{-2}$ (Table 1). Following the high winds of 17 and 18 April, chl a concentrations dropped in both Balsfjord and Ullsfjord, but had increased by 23 April in Malangen and recovered in Ullsfjord by 25 April (Fig. 3, Table 1).
The phytoplankton community composition can vary considerably among years, from mostly diatoms to mostly Phaeocystis pouchetii to variable mixtures. In April 1997, the 3 fjords exhibited somewhat different phytoplankton communities spanning this range. Diatoms made up the bulk of the phytoplankton biomass in the surface waters of all 3 fjords (Table 1). Chaetoceros socialis was the most abundant diatom, whilst Thalassiosira nordenskioeldii, T. decipens, C. socialis and other Thalassiosira spp. contributed most to the biomass. In all 3 fjords, photosynthetic nanoplankton

Table 1. Particulate organic carbon (POC), chlorophyll a (chl a) and bacterial biomass integrated to $170 \mathrm{~m}$ and the mean concentration of each in the top $20 \mathrm{~m}$. Phytoplankton biomass and that of all Phaeocystis pouchetii cells and diatoms determined by microscopy of settled samples from 1, 4 and $8 \mathrm{~m}$. Note that the estimate of phytoplankton carbon from settled samples may underestimate the contribution of small taxa. Values of gross primary production (GPP) are integrated to $20 \mathrm{~m}$. nd: no data; ${ }^{\mathrm{d} d i l u t i o n}$ experiment conducted; ${ }^{\mathrm{f}}$ FLA experiment conducted

\begin{tabular}{|c|c|c|c|c|c|c|c|c|c|c|}
\hline \multirow[t]{2}{*}{ Date } & \multicolumn{3}{|c|}{ Integrated to $170 \mathrm{~m}$} & \multicolumn{3}{|c|}{ Mean in top $20 \mathrm{~m}$} & \multicolumn{3}{|c|}{ Mean in top $8 \mathrm{~m}$} & \multirow{2}{*}{$\begin{array}{c}\text { Integrated } \\
\text { GPP } \\
\left(\mathrm{mg} \mathrm{C} \mathrm{m}^{-2} \mathrm{~d}^{-1}\right.\end{array}$} \\
\hline & $\begin{array}{c}\text { POC } \\
\left(\mathrm{g} \mathrm{m}^{-2}\right)\end{array}$ & $\begin{array}{c}\mathrm{Chl} \mathrm{a} \\
\left(\mathrm{mg} \mathrm{m}^{-2}\right)\end{array}$ & $\begin{array}{c}\text { Bacteria } \\
\left(\mathrm{mg} \mathrm{C} \mathrm{m}^{-2}\right)\end{array}$ & $\begin{array}{c}\text { POC } \\
\left(\mathrm{mg} \mathrm{m}^{-3}\right)\end{array}$ & $\begin{array}{c}\mathrm{Chl} \mathrm{a} \\
\left(\mathrm{mg} \mathrm{m}^{-3}\right)\end{array}$ & $\begin{array}{l}\text { Bacteria } \\
\left(\mathrm{mg} \mathrm{C} \mathrm{m}^{-3}\right)\end{array}$ & $\begin{array}{l}\text { Phytoplankton } \\
\left(\mathrm{mg} \mathrm{C} \mathrm{m}^{-3}\right)\end{array}$ & $\begin{array}{l}\text { P. pouchetii } \\
\left(\mathrm{mg} \mathrm{C} \mathrm{m}^{-3}\right)\end{array}$ & $\begin{array}{l}\text { Diatoms } \\
\left(\mathrm{mg} \mathrm{C} \mathrm{m}^{-3}\right)\end{array}$ & \\
\hline \multicolumn{11}{|l|}{ Balsfjord } \\
\hline $8 \mathrm{Apr}^{\mathrm{df}}$ & 19.4 & 252 & 1430 & 241 & 6.3 & 8.7 & 32 & 0.5 & 24 & nd \\
\hline $11 \mathrm{Apr}^{\mathrm{d}}$ & 27.8 & 327 & 1180 & 308 & 7.8 & 8.1 & 110 & 1.1 & 98 & 3710 \\
\hline 14 Apr ${ }^{d f}$ & 20.8 & 369 & 1160 & 409 & 11.1 & 6.9 & 140 & 2.0 & 126 & 3550 \\
\hline 17 Apr & 27.1 & 540 & nd & 413 & 10.9 & nd & 154 & 1.5 & 139 & 3820 \\
\hline $24 \mathrm{Apr}^{\mathrm{f}}$ & 31.7 & 190 & nd & 249 & 2.7 & nd & 44 & 1.2 & 37 & 1902 \\
\hline \multicolumn{11}{|c|}{ Malangen } \\
\hline $9 \mathrm{Apr}^{\mathrm{d}}$ & 34.6 & 322 & 1450 & 299 & 5.4 & 9.6 & 60 & 3.2 & 52 & 2160 \\
\hline $12 \mathrm{Apr}^{\mathrm{d}}$ & 18.2 & 195 & 1160 & 294 & 4.5 & 9.2 & 91 & 3.7 & 76 & 2380 \\
\hline $15 \mathrm{Apr}^{\mathrm{d}}$ & 14.8 & 110 & 1030 & 135 & 2.7 & 6.8 & 68 & 2.4 & 58 & 2480 \\
\hline $23 \mathrm{Apr}^{\mathrm{f}}$ & 21.4 & 241 & nd & 353 & 5.2 & nd & 369 & 8.0 & 350 & 1350 \\
\hline \multicolumn{11}{|l|}{ Ullsfjord } \\
\hline $10 \mathrm{Apr}$ df & 28.7 & 426 & 1350 & 310 & 6.7 & 9.9 & 70 & 8.8 & 50 & 3330 \\
\hline $13 \mathrm{Apr}^{\mathrm{df}}$ & 27.3 & 477 & 1400 & 281 & 5.4 & 11.00 & 106 & 9.8 & 88 & 4310 \\
\hline $16 \mathrm{Apr}^{\mathrm{df}}$ & 35.9 & 499 & 1400 & 382 & 7.1 & 9.5 & 108 & 18.7 & 72 & 2410 \\
\hline 22 Apr & 21.1 & 206 & nd & 316 & 2.2 & nd & 20 & 5.8 & 5 & 2060 \\
\hline $25 \mathrm{Apr}$ & 20.4 & 343 & nd & 367 & 5.8 & nd & 124 & 30.3 & 83 & nd \\
\hline
\end{tabular}


co-occurred with diatoms and $P$. pouchetii colonies. $P$. pouchetii biomass was highest in Ullsfjord, increasing from $8.8 \mathrm{mg} \mathrm{C} \mathrm{m}^{-3}$ on 10 April to $18.7 \mathrm{mg} \mathrm{C} \mathrm{m}^{-3}$ by 16 April and reaching $30.3 \mathrm{mg} \mathrm{C} \mathrm{m}^{-3}$ by 25 April in the top $8 \mathrm{~m}$ (Table 1). In Balsfjord, $P$. pouchetii biomass was considerably lower (0.5 to $2.0 \mathrm{mg} \mathrm{C} \mathrm{m}^{-3}$ ) with intermediate concentrations occurring in Malangen (Table 1).

\section{Bacteria}

The mean bacterial cell volume was $0.022 \pm 0.007$ (SD) $\mu^{3}$. Bacteria concentrations were similar among the fjords, varied little over the upper $100 \mathrm{~m}$, and were extremely stable over time (Table 1). Bacteria varied only from 3.2 to $6.3 \times 10^{5}$ cells ml $\mathrm{m}^{-1}$ and 5.3 to $11.5 \mathrm{mg}$ $\mathrm{C} \mathrm{m}^{-3}$. The mean water column concentration for all 3 fjords was $8 \mathrm{mg} \mathrm{C} \mathrm{m}^{-3}$. Relationships were not apparent between bacteria concentrations and hydrography, phytoplankton composition, or biomass.

\section{Microzooplankton}

The average biomass of heterotrophic protozoa $<200 \mu \mathrm{m}$ integrated to $170 \mathrm{~m}$ was higher in Ullsfjord (6820 $\mathrm{mg} \mathrm{C} \mathrm{m}^{-2}$ ) than Balsfjord (4560 $\mathrm{mg} \mathrm{C} \mathrm{m}^{-2}$ ) and Malangen (4450 $\mathrm{mg} \mathrm{C} \mathrm{m}^{-2}$ ) (Table 2). The nanoflagellate, dinoflagellate and ciliate populations contributed similar proportions to the total microzooplankton biomass (Table 2).

Nanoflagellates were typically $<8 \mu \mathrm{m}$ in diameter, mean cell volume was $77 \mu^{3}$ and mean abundance was $1.2 \times 10^{6}$ cells $1^{-1}$. They included many chrysophytes and choanoflagellates. Common taxa were Bodo, Paraphysomonas, Cafeteria, and Monosiga. Nanoflagellates were homogeneously distributed in the upper 20 to $40 \mathrm{~m}$ and then decreased with depth; abundant communities extended to 40 to $60 \mathrm{~m}$ in Ullsfjord. Concentrations in the upper $20 \mathrm{~m}$ were 20 to $35 \mathrm{mg} \mathrm{C}$ $\mathrm{m}^{-3}$ in Balsfjord, 20 to $40 \mathrm{mg} \mathrm{C}$ $\mathrm{m}^{-3}$ in Ullsfjord, and 25 to $50 \mathrm{mg}$ $\mathrm{C} \mathrm{m}^{-3}$ in Malangen. The mean water column concentration for all 3 fjords was $23 \mathrm{mg} \mathrm{C} \mathrm{m}{ }^{-3}$.

Heterotrophic dinoflagellates were typically $>15 \mu \mathrm{m}$ in diameter, mean cell volume was 19.6 $\times 10^{3} \mu^{3}$ and mean abundance was 6200 cells $\mathrm{l}^{-1}$. They included taxa of Gyrodinium and Protoperidinium. Heterotrophic dinoflagellates were homogeneously distributed in the upper $20 \mathrm{~m}$ in Malangen and the upper $40 \mathrm{~m}$ elsewhere, and then decreased with depth. Dinoflagellate biomass was similar in all 3 fjords, with typical concentrations in the upper $20 \mathrm{~m}$ of 20 to $30 \mathrm{mg} \mathrm{C} \mathrm{m}^{-3}$. The mean water column concentration for all 3 fjords was $17 \mathrm{mg} \mathrm{C} \mathrm{m}^{-3}$.

All 3 fjords contained a similar diverse ciliate community and included oligotrichs, choreotrichs, and holotrichs. Common taxa were Lohmanniella, Strobilidium, Strombidium, and Laboea. Mesodinium was also common but was considered to be a functional autotroph. Tintinnids occurred regularly but seldom in abundance. Ciliates were homogeneously distributed in the upper $20 \mathrm{~m}$ and then decreased with depth, except in Ullsfjord where their concentrations extended to 40 to $60 \mathrm{~m}$. Ciliate biomass was highest in Ullsfjord and lowest in Balsfjord. Concentrations in the upper $20 \mathrm{~m}$ were 15 to $25 \mathrm{mg} \mathrm{C} \mathrm{m}^{-3}$ in Balsfjord, 15 to $30 \mathrm{mg} \mathrm{C} \mathrm{m}{ }^{-3}$ in Ullsfjord, and 20 to $40 \mathrm{mg} \mathrm{C} \mathrm{m}^{-3}$ in Malangen. The mean water column concentration for all 3 fjords was $18 \mathrm{mg} \mathrm{C} \mathrm{m}^{-3}$. A more detailed investigation of the variation in taxonomy, abundance and biomass of the ciliate populations was made to support the FLA experiments (see 'Results: Herbivory: FLA experiments').

\section{Gross primary production (GPP)}

On the first 3 dates of sampling in each fjord, GPP averaged 3690, 2340 and $3230 \mathrm{mg} \mathrm{C} \mathrm{m} \mathrm{m}^{-1}$ in Balsfjord, Malangen and Ullsfjord, respectively (Table 1). Once

Table 2. Biomass of heterotrophic protozoans in Balsfjord, Malangen and Ullsfjord between 8 and 16 April. Values are: the mean total biomass of samples collected at 5 depths from 0 to $20 \mathrm{~m}$; total biomass integrated to $170 \mathrm{~m}$; and the contribution to total integrated biomass of nanoflagellates, dinoflagellates and ciliates

\begin{tabular}{|c|c|c|c|c|c|}
\hline Date & $\begin{array}{l}\text { Biomass in } \\
\text { top } 20 \mathrm{~m} \\
\left.(\mathrm{mg} \mathrm{C} \mathrm{m})^{-3}\right)\end{array}$ & $\begin{array}{c}\text { Integrated to } \\
170 \mathrm{~m} \\
\left(\mathrm{mg} \mathrm{C} \mathrm{m}^{-2}\right)\end{array}$ & $\begin{array}{c}\text { Proportion } \\
\text { Nanoflagellates }\end{array}$ & $\begin{array}{l}\text { of total biomass } \\
\text { Dinoflagellates }\end{array}$ & $\begin{array}{l}\text { s ( }(\%) \\
\text { Ciliates }\end{array}$ \\
\hline \multicolumn{6}{|c|}{ Balsfjord } \\
\hline 8 Apr & 57 & 3540 & 34 & 35 & 31 \\
\hline $11 \mathrm{Apr}$ & 70 & 5250 & 32 & 40 & 29 \\
\hline 14 Apr & 89 & 4900 & 34 & 36 & 31 \\
\hline \multicolumn{6}{|c|}{ Malangen } \\
\hline 9 Apr & 81 & 5870 & 40 & 24 & 37 \\
\hline $12 \mathrm{Apr}$ & 77 & 3770 & 42 & 25 & 34 \\
\hline 15 Apr & 41 & 3700 & 40 & 30 & 30 \\
\hline \multicolumn{6}{|c|}{ Ullsfjord } \\
\hline $10 \mathrm{Apr}$ & 78 & 6910 & 44 & 27 & 29 \\
\hline $13 \mathrm{Apr}$ & 60 & 6380 & 42 & 27 & 31 \\
\hline $16 \mathrm{Apr}$ & 101 & 7160 & 41 & 26 & 33 \\
\hline
\end{tabular}


sampling resumed on and following the 22 April, GPP had decreased in all 3 fjords. The relatively high GPP in Balsfjord remained constant up to 17 April and resulted in increasing integrated chl a concentrations. In contrast, despite the constant GPP in Malangen, integrated chl a concentrations decreased between 9 and 15 April. In Ullsfjord, the reduced GPP measured on the 16 April may have been the result of particularly low irradiance on that date (Fig. 2), as high GPP was generated by a similar level of chl a on the previous visits (Table 1).

\section{Herbivory}

\section{Dilution experiments}

Three dilution experiments were conducted during the first 3 visits to each fjord (Table 3 ). The large size of a high proportion of the phytoplankton is illustrated by the fact that the chl a concentrations measured at the start of the dilution experiments $\left(C_{0}\right.$, Table 3$)$ averaged 25,50 and $50 \%$ of the total measured in near-surface samples (Fig. 3) in Balsfjord, Malangen and Ullsfjord, respectively. Despite the differences in phytoplankton composition, biomass, and their trends over time, measured community growth and grazing rates on phytoplankton that passed through a $200 \mu \mathrm{m}$ mesh were similar among the fjords. In Balsfjord phytoplankton growth ranged from 0.40 to $0.46 \mathrm{~d}^{-1}$ during 8 to 14 April, whilst chl a production increased from 0.8 to $1.6 \mathrm{mg} \mathrm{m}^{-3}$ (Table 3). Microzooplankton removed an average of $68 \%$ of this production on the 3 dates. This trend is supported by increases in microzooplankton standing stocks (Table 2). In Malangen (Table 3), phytoplankton growth rates during 9 to 15 April ranged from 0.35 to $0.29 \mathrm{~d}^{-1}$ with an average production of chl $a$ of $0.75 \mu \mathrm{g} \mathrm{l}^{-1} \mathrm{~d}^{-1}$. Despite a decline in biomass of the microzooplankton (Table 2) they consumed a similar quantity of chl a (0.53 to $0.38 \mu \mathrm{g} \mathrm{l}^{-1} \mathrm{~d}^{-1}$ ) on the 3 days on which experiments were conducted, amounting to on average $63 \%$ $\mathrm{d}^{-1}$ of the chl a production. In Ullsfjord phytoplankton growth ranged from 0.45 to $0.50 \mathrm{~d}^{-1}$ and chl a production was higher than in the other 2 fjords (1.5 to $2.3 \mu \mathrm{g}^{-1} \mathrm{~d}^{-1}$ ). Microzooplankton removed a slightly lower proportion of the production (average $55 \% \mathrm{~d}^{-1}$ ) than in the other 2 fjords (Table 3 ).
FLA experiments

From the FLA experiments it was possible to distinguish between 5 FLA-consuming and 8 non FLA-consuming taxa (Table 4) using acid Lugol's fixed samples. FLA-consuming taxa made up an average of $70 \%$ (range 46 to $85 \%$ ) of the total ciliate abundance, except on 25 April in Ullsfjord, when only $8 \%$ of cells belonged to taxa that consumed FLA (Table 5). Similar taxa were found in the surface waters of each fjord, although the abundance of each taxon varied. Of the 5 taxonomic groups, Strombidium sp. 1 contributed the highest proportion of biomass in most samples, in particular in Balsfjord. Although, the most abundant taxon in Balsfjord was Strombidium spp. 2, possibly comprising more than 1 species of similar size and morphology. Numbers of Strombidium spp. 2 increased throughout the study period from 130 cells $1^{-1}$ on 8 April to 870 cells $\mathrm{l}^{-1}$ on 24 April, equivalent to 5 and $19 \%$ of the total ciliate biomass, respectively. In contrast, the most common FLA-consuming taxa in surface samples from Ullsfjord was a relatively small (Table 4) oligotrich, Lohmanniella spp., which declined from 1610 cells $\mathrm{l}^{-1}$ on 10 April to 660 cells $1^{-1}$ on 25 April. This amounted to a contribution to total ciliate biomass of between 20 and $1 \%$, respectively. These differences are reflected in the average size of FLA-consuming cells (total biomass/total abundance) in each fjord. Average cell biomass ranged from 2920 to 1620 pg C in Balsfjord, was $1570 \mathrm{pg} \mathrm{C}$ in the 2 samples from Malangen and de-

Table 3. Results of the dilution experiments showing the growth and grazing mortality of the $<200 \mu \mathrm{m}$ phytoplankton in surface waters. $k=$ phytoplankton growth coefficient; $g=$ grazing coefficient; $C_{0}=$ initial $\mathrm{chl} a$ concentration; $\hat{C}=$ mean chl $a$ concentration $=\left(C_{\mathrm{t}}-C_{0}\right) /\left(\ln C_{\mathrm{t}}-\ln C_{0}\right) ; P_{\mathrm{p}}=$ phytoplankton production $=(\mathrm{k} \cdot \hat{\mathrm{c}}) ; P_{\mathrm{c}}=$ production consumed $=(\mathrm{g} \cdot \hat{\mathrm{C}}) ; P_{\mathrm{g}}=\%$ production grazed $=(\mathrm{k} / \mathrm{g})(100)$. The $\mathrm{r}^{2}$ values of the model 1 linear regressions of 10 incubations spanning 5 levels of dilution for each experiment ranged from 0.89 to 0.97

\begin{tabular}{|lccccccc|}
\hline Date & $\begin{array}{c}k \\
\left(\mathrm{~d}^{-1}\right)\end{array}$ & $\begin{array}{c}g \\
\left(\mathrm{~d}^{-1}\right)\end{array}$ & $\begin{array}{c}C_{0} \\
\left(\mu \mathrm{g} \mathrm{l}^{-1}\right)\end{array}$ & $\begin{array}{c}\hat{\mathrm{C}} \\
\left(\mu \mathrm{g} \mathrm{l}^{-1}\right)\end{array}$ & $\begin{array}{c}P_{\mathrm{p}} \\
\left(\mu \mathrm{g} \mathrm{l}^{-1} \mathrm{~d}^{-1}\right)\end{array}$ & $\begin{array}{c}P_{\mathrm{c}} \\
\left(\mu \mathrm{I} \mathrm{l}^{-1} \mathrm{~d}^{-1}\right)\end{array}$ & $\begin{array}{c}P_{\mathrm{g}} \\
(\%)\end{array}$ \\
\hline Balsfjord & & & & & & & \\
8 Apr & 0.40 & 0.21 & 1.6 & 2.0 & 0.79 & 0.42 & 53 \\
$11 \mathrm{Apr}$ & 0.38 & 0.28 & 1.8 & 2.2 & 0.83 & 0.62 & 74 \\
14 Apr & 0.46 & 0.36 & 2.8 & 3.6 & 1.64 & 1.28 & 78 \\
Mean & 0.41 & 0.28 & 2.1 & 2.5 & 1.03 & 0.70 & 68 \\
Malangen & & & & & & & \\
9 Apr & 0.35 & 0.20 & 2.2 & 2.6 & 0.92 & 0.53 & 57 \\
12 Apr & 0.31 & 0.22 & 2.0 & 2.3 & 0.73 & 0.51 & 71 \\
15 Apr & 0.29 & 0.18 & 1.8 & 2.1 & 0.61 & 0.38 & 62 \\
Mean & 0.32 & 0.20 & 2.0 & 2.3 & 0.75 & 0.47 & 63 \\
Ullsfjord & & & & & & & \\
10 Apr & 0.45 & 0.21 & 2.6 & 3.3 & 1.47 & 0.69 & 47 \\
13 Apr & 0.50 & 0.31 & 3.5 & 4.5 & 2.27 & 1.41 & 62 \\
16 Apr & 0.46 & 0.25 & 2.5 & 3.2 & 1.46 & 0.79 & 54 \\
Mean & 0.47 & 0.26 & 2.9 & 3.7 & 1.74 & 0.96 & 55 \\
\hline
\end{tabular}


creased to between 610 and 950 pg C in Ullsfjord.

The concentration of Chlorella stigmatophora FLA in each incubation was similar among experiments and varied from 510 to $1140 \mathrm{FLA} \mathrm{ml}^{-1}$, with a mean of $814 \mathrm{FLA} \mathrm{ml}^{-1}$. This equates to a mean relative abundance (FLA plus phototrophic cells of similar size) of $19 \%$ (range 10 to $28 \%$ ). The interpretation of the clearance rates calculated from the FLA experiments assumes that no variations in feeding response in relation to prey density occurred between experiments. In addition, no attempt was made to determine if ciliates discriminated against the FLA compared to natural nanophytoplankton prey. FLA uptake rates by the ciliates were generally linear for $\geq 30$ min. Mean cell-specific clearance rates were correlated with ciliate cell size, and ranged from Strombidium sp. 1, which cleared an average of $5.55 \mu$ cell $^{-1} \mathrm{~h}^{-1}$, to Lohmanniella spp., which cleared an average of $1.31 \mu \mathrm{l} \mathrm{cell}{ }^{-1} \mathrm{~h}^{-1}$ (Table 4 ).

The variations in the composition of the ciliate population between fjords are reflected in the relative contributions of the taxa to total clearance rates (Table 5). In Balsfjord the water cleared each day increased from $43 \mathrm{ml} \mathrm{l}^{-1} \mathrm{~d}^{-1}$ on 8 April to $141 \mathrm{ml} \mathrm{l}^{-1} \mathrm{~d}^{-1}$ on 24 April (Table 5). Both Strombidium sp. 1 and Strombidium
Table 4. Ciliate taxonomy, cell size $\left(D_{\max }\right)$ and cell-specific clearance rates determined in the near-surface water sampled for FLA experiments from the 3 fjords. $(\times)$ Taxa that were not observed to ingest FLA. Values are means $\pm \mathrm{SD}$. Note that Mesodinium sp. is not known to ingest prey

\begin{tabular}{|lccc|}
\hline Taxon & $\begin{array}{c}\text { Cell } D_{\max } \\
(\mu \mathrm{m})\end{array}$ & $\begin{array}{c}\text { Cell volume } \\
\left(10^{3} \mu \mathrm{m}^{3}\right)\end{array}$ & $\begin{array}{c}\text { Clearance rate } \\
\left(\mu \mathrm{l} \mathrm{cell} \mathrm{l}^{-1} \mathrm{~h}^{-1}\right)\end{array}$ \\
\hline Strombidium sp. 1 & $57.1 \pm 9.9$ & $30.3 \pm 12.4$ & $5.55 \pm 1.23$ \\
Lohmanniella spp. & $16.7 \pm 2.2$ & $1.3 \pm 0.5$ & $1.31 \pm 0.64$ \\
Strobilidium sp. & $33.4 \pm 10.9$ & $6.0 \pm 1.5$ & $3.28 \pm 0.45$ \\
Strombidium spp. 2 & $32.3 \pm 5.9$ & $6.3 \pm 2.8$ & $3.49 \pm 0.88$ \\
Strombidiid small & $43.8 \pm 13.1$ & $6.6 \pm 4.2$ & $3.81 \pm 0.65$ \\
& $96.8 \pm 23.4$ & $43.9 \pm 8.3$ & $\times$ \\
Laboea sp. large & $126.8 \pm 14.4$ & $115.9 \pm 39.9$ & $\times$ \\
Strombidium sp. 3 & $76.2 \pm 10.7$ & $132.8 \pm 60.8$ & $\times$ \\
Choreotrich sp. 1 & $22.5 \pm 2.9$ & $2.5 \pm 1.0$ & $\times$ \\
Choreotrich sp. 2 & $26.7 \pm 3.0$ & $6.2 \pm 2.2$ & $\times$ \\
Stensomella sp. & 56.7 & 22.8 & $\times$ \\
Tintinnid(s) & $35.0 \pm 6.5$ & $9.3 \pm 6.1$ & $\times$ \\
Holotrich spp. & $30.7 \pm 9.1$ & $6.1 \pm 4.9$ & $\times$ \\
Mesodinium sp. & $39.3 \pm 4.2$ & $19.7 \pm 6.3$ & \\
\hline
\end{tabular}

spp. 2 were major contributors to total ciliate clearance rates. In particular, the clearance rates of the Strombidium spp. 2 population reached a maximum of $82 \mathrm{ml} \mathrm{l}^{-1}$ $\mathrm{d}^{-1}$ on 24 April (Table 5). Total ciliate clearance rates were similar in Ullsfjord, where a maximum of $90 \mathrm{ml} \mathrm{l}^{-1}$ $\mathrm{d}^{-1}$ was cleared on 13 April. In contrast to Balsfjord, the Lohmanniella sp. population had the highest clearance rates in Ullsfjord, reaching a maximum of $66 \mathrm{ml} \mathrm{l}^{-1} \mathrm{~d}^{-1}$ on 13 April (Table 5). In the 1 experiment carried out in Malangen total ciliate clearance was low and was

Table 5. Ciliate abundance and clearance rates in near-surface waters used for the FLA experiments. Taxon-specific clearance rates of FLA (mean $\pm \mathrm{SD}$ ) were calculated from the mean abundance and the cell-specific clearance rate from 3 incubations on each date. Exceptions are: *values of cell-specific clearance were calculated from the combined FLA uptake rate of cells in all 3 incubations; ${ }^{* *}$ values are based on cell-specific clearance rates calculated on a different date at the same site; ${ }^{* * *}$ only 1 incubation was conducted on 23 April, from which the regression of FLA uptake versus time (min) is $0.031 \pm 0.000$ (SE). The relationship between total FLA uptake cell ${ }^{-1}$ and incubation time was used to calculate a cell-specific and total clearance for the combined FLA-consuming population. No FLA experiments were conducted on 9,17 and 25 April

\begin{tabular}{|c|c|c|c|c|c|c|c|c|c|}
\hline \multirow[t]{2}{*}{ Date } & \multicolumn{2}{|c|}{$\begin{array}{l}\text { Abundance } \\
\left(\text { cells } 1^{-1}\right)\end{array}$} & \multicolumn{5}{|c|}{$\begin{array}{c}\text { Taxon-specific population clearance rate }- \\
\left(\mathrm{ml} \mathrm{l}^{-1} \mathrm{~d}^{-1}\right)\end{array}$} & \multicolumn{2}{|c|}{$\begin{array}{l}\text { Combined FLA-consuming } \\
\text { population clearance }\end{array}$} \\
\hline & Total & $\begin{array}{l}\text { FLA- } \\
\text { consuming }\end{array}$ & $\begin{array}{l}\text { Strombi- } \\
\text { dium sp. } 1\end{array}$ & $\begin{array}{l}\text { Lohman- } \\
\text { niella spp. }\end{array}$ & $\begin{array}{l}\text { Strobili- } \\
\text { dium sp. }\end{array}$ & $\begin{array}{l}\text { Strombi- } \\
\text { dium spp. } 2\end{array}$ & $\begin{array}{l}\text { Strombidiid } \\
\text { small and large }\end{array}$ & $\begin{array}{l}\text { Cell-specific } \\
\left(\mu \mathrm{l} \mathrm{cell}{ }^{-1} \mathrm{~d}^{-1}\right)\end{array}$ & $\begin{array}{c}\text { Total } \\
\left(\mathrm{ml} \mathrm{l}^{-1} \mathrm{~d}^{-1}\right)\end{array}$ \\
\hline \multicolumn{10}{|c|}{ Balsfjord } \\
\hline $8 \mathrm{Apr}$ & $950 \pm 210$ & $520 \pm 180$ & $28 \pm 3$ & $2^{* *}$ & 0 & $12 \pm 3$ & $1^{* *}$ & $88 \pm 28$ & $43 \pm 14$ \\
\hline $14 \mathrm{Apr}$ & $1380 \pm 560$ & $730 \pm 300$ & $36 \pm 4$ & $1^{* *}$ & 0 & $36 \pm 9$ & $4^{* *}$ & $116 \pm 32$ & $85 \pm 23$ \\
\hline $17 \mathrm{Apr}$ & $1470 \pm 220$ & $1370 \pm 200$ & - & - & - & - & - & - & - \\
\hline 24 Apr & $2470 \pm 590$ & $1610 \pm 450$ & $22 \pm 8$ & $8 \pm 1$ & 0 & $82 \pm 3$ & $9^{*}$ & $88 \pm 5$ & $141 \pm 9$ \\
\hline \multicolumn{10}{|c|}{ Malangen } \\
\hline 9 Apr & $1100 \pm 110$ & $870 \pm 130$ & - & - & - & - & - & - & - \\
\hline $23 \mathrm{Apr}$ & $1820 \pm 390$ & $840 \pm 220$ & 11 & 1 & 4 & 4 & 4 & 40 & $27^{* * *}$ \\
\hline \multicolumn{10}{|c|}{ Ullsfjord } \\
\hline $10 \mathrm{Apr}$ & $2370 \pm 580$ & $1890 \pm 510$ & $16^{*}$ & $40 \pm 6$ & $8^{* *}$ & $1^{* *}$ & $1^{* *}$ & $26 \pm 2$ & $49 \pm 4$ \\
\hline $13 \mathrm{Apr}$ & $2030 \pm 720$ & $1730 \pm 690$ & $28 \pm 14$ & $66 \pm 21$ & $7^{*}$ & $17 \pm 4$ & $5^{*}$ & $52 \pm 6$ & $90 \pm 10$ \\
\hline 16 Apr & $1250 \pm 40$ & $940 \pm 60$ & $6^{*}$ & $20 \pm 1$ & $1^{* *}$ & $1^{* *}$ & $6^{* *}$ & $30 \pm 4$ & $28 \pm 3$ \\
\hline $25 \mathrm{Apr}$ & $10260 \pm 1080$ & $870 \pm 40$ & - & - & - & - & - & - & - \\
\hline
\end{tabular}


dominated by Strombidium sp. 1 (Table 5). Despite variations in the taxonomy of the primary grazers among sites, the trends in measured clearance rate of the ciliate population are explained to a large extent by the total biovolume of the FLA-consuming taxa (Fig. 4).

\section{DISCUSSION}

The high biomass of microzooplankton (3500 to $7200 \mathrm{mg} \mathrm{C} \mathrm{m}{ }^{-2}$, Table 2) in all 3 fjords throughout the first $9 \mathrm{~d}$ of the study is an indication of their importance to the structure and function of the planktonic communities.

\section{Microzooplankton impact on phytoplankton production and progression of the bloom}

The results of the dilution experiments allow an estimate of the grazing impact of the microzooplankton. From 8 to 16 April, the average microzooplankton ingestion rates in near-surface waters, estimated from 3 dilution experiments at each site, were equivalent to 68,63 and $55 \% \mathrm{~d}^{-1}$ of the $<200 \mu \mathrm{m}$ phytoplankton production (Table 3). Phytoplankton and microzooplankton biomass remained relatively constant throughout the top $20 \mathrm{~m}$ of the water column in all 3 fjords (Fig. 3, Table 2). Therefore, it is reasonable to integrate grazing rates measured in the dilution experi-

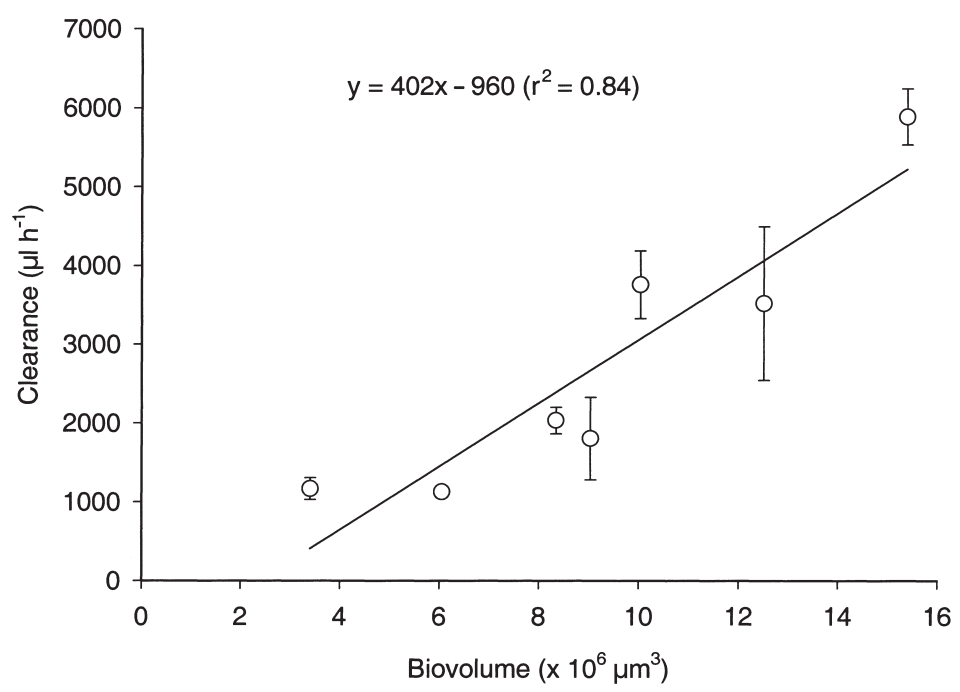

Fig. 4. Relationship between biovolume of the FLA-consuming ciliate population and clearance rate on the 7 days on which FLA experiments were conducted. Error bars are standard deviations of the mean clearance rate determined from 3 incubations. Note that on 23 April only 1 incubation was carried out ments to this depth. Using a microzooplankton biomass-specific rate of ingestion ( $\mu \mathrm{g}$ chl a $\mu \mathrm{g} \mathrm{C}^{-1} \mathrm{~d}^{-1}$ ) from the dilution experiments, a value for chl a ingestion integrated to $20 \mathrm{~m}$ can be calculated and an estimate made of the GPP consumed (Table 6). The average integrated ingestion rates of chl a were $18.5 \mathrm{mg}$

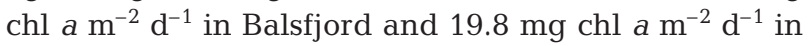
Ullsfjord, considerably higher than in Malangen,

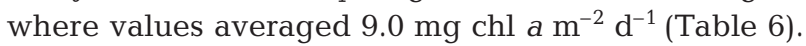
This level of ingestion represents a similar proportion of on average $13 \% \mathrm{~d}^{-1}$ of the chl a standing stocks. An upper estimate of phytoplankton carbon can be calculated from POC minus bacterial and microzooplankton biomass. The ingestion of phytoplankton biomass, calculated from the ratio of phytoplankton carbon: chl $a$, integrated to $20 \mathrm{~m}$, averaged 520, 340 and $710 \mathrm{mg} \mathrm{C} \mathrm{m}^{-2} \mathrm{~d}^{-1}$ in Balsfjord, Malangen and Ullsfjord, respectively (Table 6).

Eilertsen \& Taasen (1984) considered the culmination of the spring bloom in Balsfjord in 1976 to 1978 to be the result of the combined effects of lowered nutrient concentrations, lowered light availability and increased mesozooplankton grazing pressure. Based on information on phytoplankton composition and nutrient concentrations, the spring bloom in Ullsfjord and Malangen appeared to precede that in Balsfjord by approximately $2 \mathrm{wk}$ (Reigstad et al. unpubl.). Despite this, the growth rates of $<200 \mu \mathrm{m}$ phytoplankton $(k$, Table 3) determined from dilution experiments, were similar among fjords and exceeded the mortality due to microzooplankton grazing ( $g$, Table 3 ) on all the days examined. In Balsfjord phytoplankton biomass (chl a) continued to increase up to 17 April and maintain relatively high gross production (Fig. 3, Table 1), even though the grazing pressure by the microzooplankton increased (Tables 3 \& 6). In Malangen, microzooplankton grazing remained relatively constant and consumed on average $15 \% \mathrm{~d}^{-1}$ of GPP (Table 6), which may account in part for the decreasing phytoplankton biomass (Fig. 3, Table 1). In Ullsfjord, microzooplankton consumed a higher proportion of the GPP, on average $21 \% \mathrm{~d}^{-1}$ (Table 6), but phytoplankton biomass remained relatively stable from 10 to 16 April (Fig. 3, Table 1). Climatic factors also appeared to play a role in the progression of the bloom in each fjord. The period from 16 to 18 April was a time of poor weather with low irradiances and air temperatures and relatively high winds from the south and west (Fig. 2). This appeared to cause a decrease in surface chl a concentrations, particularly in Balsfjord and Ullsfjord, possibly due to greater mixing of the water column. However, the large gap in the sampling period, in part due to the weather, makes interpretation of the cause of the changes in biomass and community composition after 17 April unclear. 
The spring bloom of 1997 was characterised by a low biomass of Phaeocystis pouchetii (Table 1). For instance, $P$. pouchetii reached a biomass of between 10 and $100 \mathrm{mg} \mathrm{C} \mathrm{m}^{-3}$ and comprised almost $50 \%$ of the phytoplankton carbon in the upper waters of Balsfjord in the spring of 1982 (Lutter et al. 1989) and 1992 (Riebesell et al. 1995). The transition from single to colonial growth phase by Phaeocystis has been hypothesised as an adaptation to minimise losses to suspension-feeding zooplankton (Hansen et al. 1994). The triggers that initiate the transition from solitary to colonial growth phase are not fully understood, although both phosphate and inorganic nitrogen availability (Velhuis \& Admiraal 1987, Riegman et al. 1992) and levels of daily irradiance (Peperzak 1993) have been implicated. In view of the fact that the phytoplankton assemblages in each of the fjords were dominated by diatoms (Table 1), the microzooplankton grazing pressure on nanophytoplankton, including single $P$. pouchetii cells, may have been higher than that on the $<200 \mu \mathrm{m}$ population as a whole. The high proportion of sedimenting particulate carbon that consisted of diatom cells (18 to $21 \%$ at $160 \mathrm{~m}$ ) during the present study (Reigstad et al. unpubl.), supports the view that there was a relatively low grazing pressure on the larger components of the phytoplankton. A similarly active microzooplankton population was found during late spring in western Norwegian fjords (Verity \& Vernet 1992). In that case, grazing by $<200 \mu \mathrm{m}$ microzooplankton generally removed 50 to $100 \%$ and 20 to $100 \%$ of production by cells $<10$ and $<2 \mu \mathrm{m}$ including autotrophic and heterotrophic forms, respectively. Certainly, an active ciliate population able to graze on prey of a similar size to single $P$. pouchetii occurred in all 3 fjords.

\section{Ciliates and their contribution to the grazing impact}

Ciliate ingestion/clearance rates are governed by a complex interplay between encounter rate, capture of prey and handling time which may include a period of assessment, possibly involving chemosensory behaviour, followed by digestion (Verity 1991). The most likely sources of error in clearance rates determined in the FLA experiments are associated with encounter rate and assessment of prey. In the present study FLA were added at $\sim 1000$ cells $\mathrm{ml}^{-1}$ in order to obtain quantifiable uptake rates. This was greater than $10 \%$ of the natural concentration of nanophytoplankton cells (data not shown). The functional response of zooplankton to variations in prey concentration is often described by Michaelis-Menten type kinetics, with increasing food concentration resulting in increased ingestion up to a threshold value where saturation occurs (Mullin et al. 1975, Fenchel 1980, Verity 1991, Berges et al. 1994). The half-saturation values $\left(K_{\mathrm{m}}\right)$ for ingestion/growth of grazers are generally close to the concentration of their natural prey, and the relationship between prey concentration and ingestion rate approximates first-order kinetics close to and below $K_{\mathrm{m}}$. Therefore, the addition of FLA may have caused an increase in ingestion rate and an overestimate of clearance rates (MacManus \& Okuba 1991). It is possible that selection by ciliates for or against FLA relative to natural prey occurred in the present study, but it was not tested. However, the uptake rates of FLA by ciliates were generally linear, suggesting that selectivity did not alter over the short duration of the incubations.

In addition to prey concentration and nutritional value, predator size, morphology and temperature are

Table 6. Estimates of the impact of microzooplankton herbivory on the standing stock of chlorophyll a (chl a), phytoplankton carbon, gross primary production (GPP) and the GPP ingested per day as \% of microzooplankton (MZP) biomass. All values are integrated to a depth of $20 \mathrm{~m}$. A microzooplankton biomass-specific ingestion rate of chl a from the dilution experiments was used to calculate the integrated chl $a$ ingestion rate. Phytoplankton biomass was calculated from POC (particulate organic carbon) minus bacterial and microzooplankton biomass. This assumes that these 3 components of the plankton made up the total POC. The carbon ingested was calculated from the chl a ingested and values of phytoplankton carbon:chl $a$ on each date. nd: not determined

\begin{tabular}{|c|c|c|c|c|c|c|c|}
\hline Date & $\begin{array}{l}\text { MZP biomass } \\
\left(\mathrm{mg} \mathrm{C} \mathrm{m}^{-2}\right)\end{array}$ & $\begin{array}{c}\mathrm{Chl} \mathrm{a} \\
\left(\mathrm{mg} \mathrm{m}^{-2}\right)\end{array}$ & $\begin{array}{l}\text { Phytoplankton } \\
\quad\left(\mathrm{mg} \mathrm{C} \mathrm{m}^{-2}\right)\end{array}$ & $\begin{array}{l}\text { Chl } a \text { ingested } \\
\left(\mathrm{mg} \mathrm{m}^{-2} \mathrm{~d}^{-1}\right)\end{array}$ & $\begin{array}{l}\text { Carbon ingested } \\
\qquad\left(\mathrm{mg} \mathrm{m}^{-2} \mathrm{~d}^{-1}\right)\end{array}$ & $\begin{array}{l}\text { GPP ingested } \\
\qquad\left(\% \mathrm{~d}^{-1}\right)\end{array}$ & $\begin{array}{l}\text { GPP ingested per day } \\
\text { as } \% \text { of MZP biomass }\end{array}$ \\
\hline \multicolumn{8}{|c|}{ Balsfjord } \\
\hline $8 \mathrm{Apr}$ & 1220 & 125 & 3380 & 11.4 & 310 & nd & 25 \\
\hline $11 \mathrm{Apr}$ & 1520 & 157 & 4660 & 18.5 & 550 & 15 & 36 \\
\hline $14 \mathrm{Apr}$ & 1850 & 223 & 6190 & 25.7 & 710 & 20 & 39 \\
\hline \multicolumn{8}{|c|}{ Malangen } \\
\hline 9 Apr & 1620 & 107 & 4230 & 8.3 & 330 & 15 & 20 \\
\hline $12 \mathrm{Apr}$ & 1560 & 93 & 4020 & 9.5 & 410 & 17 & 26 \\
\hline $15 \mathrm{Apr}$ & 910 & 52 & 1630 & 9.3 & 290 & 12 & 32 \\
\hline \multicolumn{8}{|c|}{ Ullsfjord } \\
\hline $10 \mathrm{Apr}$ & 1590 & 137 & 4340 & 15.7 & 497 & 15 & 31 \\
\hline $13 \mathrm{Apr}$ & 1240 & 103 & 3870 & 26.4 & 990 & 23 & 80 \\
\hline $16 \mathrm{Apr}$ & 2050 & 145 & 5260 & 17.3 & 630 & 26 & 31 \\
\hline
\end{tabular}


amongst the variables that affect planktonic protistan grazing rates. Despite this, the cell-specific clearance rates of the FLA-consuming ciliates measured in the present study (1.3 to $5.6 \mu \mathrm{l} \mathrm{cell}^{-1} \mathrm{~h}^{-1}$, Table 4 ) are comparable to other in situ rates measured using tracer particles of a similar size at similar concentrations. In tidal creek waters of Georgia, USA, the ciliate community, dominated by choreotrichs, cleared FLA (1 to $2.5 \times$ $10^{4} \mathrm{ml}^{-1}$ ) at 1.2 to $8.3 \mu \mathrm{l} \mathrm{cell}{ }^{-1} \mathrm{~h}^{-1}$ (Sherr et al. 1991). In the Arabian Sea, mean clearance rates of a variety of ciliates ranged from 2.3 to $13.7 \mu \mathrm{cell}^{-1} \mathrm{~h}^{-1}$ for 4 to $10 \mu \mathrm{m}$ FLA during the southwest monsoon period and from 0.2 to $7.3 \mu \mathrm{cell}^{-1} \mathrm{~h}^{-1}$ for 2 to $4 \mu \mathrm{m}$ FLA during the intermonsoon period (Edwards et al. 1999). The clearance rates of oligotrich ciliates in the northern Baltic Sea ranged from 1.9 to $11.4 \mu \mathrm{cell}^{-1} \mathrm{~h}^{-1}$, when nanosized starch particles were used as prey analogues at concentrations of 1 to $8 \times 10^{3} \mathrm{ml}^{-1}$ (Kivi \& Setälä 1995). A volume-specific clearance rate for the FLA-consuming ciliate population of $3.1 \times 10^{5}$ volumes $\mathrm{h}^{-1}$ can be calculated from the relationship between biovolume and total clearance rates (Fig. 4). This is comparable to the volume-specific clearance of the oligotrich ciliate Strombidium sulcatum of $2.0 \times 10^{5}$ volumes $\mathrm{h}^{-1}$ measured in culture at $20^{\circ} \mathrm{C}$ (Fenchel \& Jonsson 1988) and to rates determined in coastal waters off Oregon of 0.4 to $4.0 \times 10^{5}$ volumes $\mathrm{h}^{-1}$, using a dual-label isotope technique (Neuer \& Cowles 1995).

The trends in total microzooplankton grazing impact assessed by the dilution approach (Table 3) and of the total clearance rates of FLA-consuming ciliates (Table 5) were similar in both Balsfjord and Ullsfjord. This suggests that the behaviour of the FLA-consuming ciliate population is representative of the total microzooplankton population or that a large proportion of microzooplankton grazing is due to the ciliates. The proportion of total microzooplankton grazing attributable to the FLA-consuming ciliate population can be estimated on the 5 dates when both dilution and FLA experiments were carried out. Estimates of the rate of ingestion of $<200 \mu \mathrm{m}$ chl a $(\hat{c}$, Table 3$)$ by the FLA-consuming ciliates based on the clearance rates determined in FLA experiments, are 0.09 and $0.31 \mathrm{mg} \mathrm{m}^{-3} \mathrm{~d}^{-1}$ in Balsfjord on 8 and 14 April and 0.16, 0.41 and $0.09 \mathrm{mg} \mathrm{m}^{-3} \mathrm{~d}^{-1}$ in Ullsfjord on 10, 13 and 16 April, respectively. These ingestion rates are equivalent to 20 and $24 \%$ of the total microzooplankton consumption $\left(P_{\mathrm{C}}\right.$, Table 3$)$ in dilution experiments on the same dates in Balsfjord and 23, 29 and $11 \%$ on the same dates in Ullsfjord. The values may overestimate the ciliate contribution as they do not account for predator selectivity and assume that clearance of FLA is equivalent to the clearance of chl a of $<200 \mu \mathrm{m}$. On the other hand, on average $42 \%$ of the total ciliate abundance was made up of taxa that did not ingest FLA (Table 5), some of which may be bacteri- vores or may have grazed on components of the phytoplankton not represented by the FLA. Few other direct estimates of the contribution of ciliates to the total grazing impact exist. One approach is to use specific ingestion or growth rates determined in the laboratory to apportion the relative contribution of major groups of microzooplankton. Using this approach, in the phytoflagellate-dominated waters of the North Atlantic in summer the ciliate population generally contributed 15 to $25 \%$ of the total microzooplankton ingestion rate (Verity et al. 1993), similar to estimates of the FLA-consuming ciliates in the present study. In contrast, in the equatorial Pacific, where small $(<2 \mu \mathrm{m})$ cells were the dominant component of the phytoplankton, ciliates were estimated to contribute only 1 to $5 \%$ of the total ingestion rate (Verity et al. 1996).

Direct measurements of the grazing impact of nanoflagellates and dinoflagellates were not carried out in the present study but some idea of their relative contribution to the microzooplankton grazing impact is possible. Pigmented cells were regularly seen inside the food vacuoles of heterotrophic nanoflagellates, and it is likely that they grazed on the smallest components of the phytoplankton. However, the common taxa observed in the fjords are known to be bacterivorous. The low but uniform bacterial biomass (mean of $8.9 \mathrm{mg} \mathrm{C} \mathrm{m}^{-3}$, Table 1) may have been the result of heavy grazing pressure by the nanoflagellate population (mean biomass of $28 \mathrm{mg} \mathrm{C} \mathrm{m}^{-3}$ in the upper $20 \mathrm{~m}$, Table 2). Bacterial productivity would have had to be high to support a nanoflagellate population of $>3$ times the biomass of the bacteria in the upper $20 \mathrm{~m}$. Little is known about the rates of bacterial production and fate of that production during the spring bloom in the fjords of northern Norway. Heterotrophic dinoflagellates have been shown to exert an important control on phytoplankton production in other high latitude coastal waters (e.g. Archer et al. 1996, Tiselius \& Kuylenstierna 1996, Putland 2000). In the present study heterotrophic dinoflagellates comprised between 24 and $36 \%$ of the microzooplankton biomass between 8 and 16 April, similar to that of the ciliates (Table 2). However, heterotrophic dinoflagellates are generally considered to grow more slowly than ciliates of similar size. For instance, in the Barents Sea the mean potential specific growth rate for a variety of ciliates was estimated to be $0.74 \mathrm{~d}^{-1}$, compared to $0.25 \mathrm{~d}^{-1}$ for athecate dinoflagellates, at temperatures of -1.8 to $4.0^{\circ} \mathrm{C}$ (Hansen \& Jensen 2000). If gross growth efficiencies were similar between the 2 groups and heterotrophic dinoflagellate growth rates lower, then the carbon requirements of the dinoflagellate population in the fjords of northern Norway would have been lower than those of the ciliates. The average linear size ratio between predator and optimum prey is approximately 8:1 for ciliates and 1:1 for heterotrophic 
dinoflagellates, suggesting that the 2 groups do not compete for the same phytoplankton prey (Hansen et al. 1994). It is likely that dinoflagellates were active grazers of the abundant diatom populations that occurred during the spring of 1997 (Table 1), and athecate dinoflagellates have been observed feeding on the colonial phase of Phaeocystis (Stelfox-Widdicombe et al. unpubl.). If nanoflagellates largely consumed bacteria and dinoflagellate carbon requirements were lower than those of ciliates, then the combined nanoflagellate, dinoflagellate and ciliate grazing rates do not match those measured in the dilution experiments. For a variety of reasons it is possible that FLA experiments underestimate clearance rates (see above). Alternatively, the interpretation of dilution experiments relies on several assumptions which if not satisfied may lead to an overestimate of the microzooplankton grazing impact (Landry 1993 and references therein).

An impression of the potential impact that ciliates had on the Phaeocystis pouchetii populations can be illustrated by comparing the estimates of ciliate ingestion rate with the total standing stock of the $P$. pouchetii. No information is available on the relative contribution of solitary and colonial cells to the P. pouchetii biomass, but by comparing total standing stocks to ingestion rates a lower limit to the potential grazing impact is illustrated. Using phytoplankton carbon:chl a ratios from values integrated to $20 \mathrm{~m}$ on each date (see Table 6), the rate of ingestion of $<200 \mu \mathrm{m}$ chl a (see above) can be converted to carbon ingested. Thereby, carbon ingestion rates in Balsfjord were 2.4 and $8.6 \mathrm{mg}$ $\mathrm{C} \mathrm{m}^{-3} \mathrm{~d}^{-1}$ on 8 and 14 April and in Ullsfjord were 5.1, 15.4 and $3.3 \mathrm{mg} \mathrm{C} \mathrm{m} \mathrm{d}^{-3} \mathrm{~d}^{-1}$ on 10, 13 and 16 April, respectively. These rates exceed the total standing stock of P. pouchetii in Balsfjord (0.5 and $2.0 \mathrm{mg} \mathrm{C} \mathrm{m}^{-3}$ ) and are of similar magnitude to $P$. pouchetii standing stocks in Ullsfjord (8.8, 9.8 and $18.7 \mathrm{mg} \mathrm{C} \mathrm{m}^{-3}$ ) (Table 1). In addition to the FLA-consuming ciliates, both heterotrophic nanoflagellates and dinoflagellates may have grazed on the solitary cells of $P$. pouchetii. Although many uncertainties are involved in the estimates, it is feasible that the grazing pressure on single and small colonies of $P$. pouchetii was high enough to decrease the rate of formation of larger colonial phases and reduce the overall competitiveness of the populations in the spring of 1997.

\section{Potential growth and production of the microzooplankton}

On the north Norwegian shelf, total microzooplankton biomass estimated using the same image analysis system as in the present study ranged from 15 to $90 \mathrm{mg}$ $\mathrm{C} \mathrm{m}^{-3}$ from March to October (Verity et al. 1999), com- parable to the values observed in the north Norwegian fjords in spring (Table 2). On the Norwegian shelf, the grazing impact of ciliates and dinoflagellates was estimated to be 37 to $61 \mathrm{~g} \mathrm{C} \mathrm{m}^{-2}$ ( 0.17 to $\left.0.32 \mathrm{~g} \mathrm{C} \mathrm{m}^{-2} \mathrm{~d}^{-1}\right)$ during the period from March to October, assuming a growth rate of $0.4 \mathrm{~d}^{-1}$ and a growth efficiency of 0.3 to 0.5 (Verity et al. 1999). During the same period, heterotrophic nanoflagellates dominated the microzooplankton and were estimated to have ingested 704 to $1170 \mathrm{~g}$ $\mathrm{C} \mathrm{m}^{-2}$ (3.32 to $5.52 \mathrm{~g} \mathrm{C} \mathrm{m}^{-2} \mathrm{~d}^{-1}$ ). The estimated daily consumption rates in the present study are equivalent to $20-80 \%$ of the microzooplankton biomass in the top $20 \mathrm{~m}$ (Table 6). This represents an average growth rate for the microzooplankton population in the upper $20 \mathrm{~m}$ of $0.10 \pm 0.05(\mathrm{SD}) \mathrm{d}^{-1}$, assuming a gross growth efficiency of 0.3 (Straile 1997). Microzooplankton biomass remained high throughout the water column in all the fjords (Table 2). Bacterial biomass was 1.0 to $1.4 \mathrm{~g} \mathrm{C} \mathrm{m}^{-2}$ (Table 1), showed little variation with depth and may have provided a substantial proportion of the heterotrophic protozoan diet in deeper waters. In addition, high vertical export of biogenic matter $(0.20$ to $0.85 \mathrm{~g} \mathrm{C}$ $\left.\mathrm{m}^{-2} \mathrm{~d}^{-1}\right)$, containing a large proportion of phytoplankton carbon, occurred in the spring of 1997 (Reigstad et al. unpubl.) and may have contributed to the diets of microzooplankton below the euphotic zone. Estimates of the total microzooplankton carbon requirements integrated to $170 \mathrm{~m}$, assuming a growth rate of 0.10 (see above) and growth efficiency of 0.3 , are 1.58, 1.54 and $2.37 \mathrm{~g} \mathrm{C} \mathrm{m}^{-2} \mathrm{~d}^{-1}$, averaged over the 3 sampling dates in Balsfjord, Malangen and Ullsfjord, respectively. This is equivalent to a mean of 43,67 and $76 \%$ of the GPP in Balsfjord, Malangen and Ullsfjord, respectively, illustrating the large proportion of phytoplankton production that may be channeled through microzooplankton.

The grazing rates of mesozooplankton in the 3 fjords were comparatively high during the study (Arashkevish unpubl.). Selective grazing by copepods on microzooplankton in preference to Phaeocystis single cells has been observed in laboratory culture experiments and may be a mechanism by which the grazing pressure on Phaeocystis is reduced (Hansen et al. 1993). Copepods may select for microzooplankton in their diets because they are more nutritious than the phytoplankton or synthesise essential compounds (Klein Breteler et al. 1999). A crude approximation of the carbon flow via microzooplankton to metazoan grazers is possible, assuming that the daily ration is equivalent to the production of the larger microzooplankton population. This assumption is supported by the relatively stable microzooplankton standing stocks during the study period (Table 2). The production of heterotrophic dinoflagellates plus ciliates, assuming a specific growth rate of $0.10 \mathrm{~d}^{-1}$ (see above) throughout the depth range and amongst all the components of the microzooplankton, 
averages 320, 280 and $420 \mathrm{mg} \mathrm{C} \mathrm{m}^{-2} \mathrm{~d}^{-1}$ in the top $170 \mathrm{~m}$ in Balsfjord, Malangen and Ullsfjord, respectively. This is equivalent to a mean of 9,12 and $12 \%$ of the GPP, respectively, illustrating a potentially important link between primary production and higher trophic levels.

Acknowledgements. This investigation is part of the EU ELOISE project 'Entangled sulphur and carbon fluxes in Phaeocystis-dominated ecosystems (ESCAPE (MAS3-CT960050)).' It is contribution ELOISE No. 153. We are grateful to Paul Wassmann and Marit Reigstad for the organisation of the 1997 ESCAPE field campaign and together with Sygrid Øygarden for support in the laboratory and field. The authors also gratefully acknowledge the efforts of the crew of the RV 'Johan Rudd'. We are grateful also to the University of Tromsø for the use of their facilities and to the Storm Cast project, University of Tromsø, for meteorological data. Thanks to Edwin de Jong, who was responsible for the practical side of the productivity measurements. We thank the 3 anonymous reviewers who offered constructive comments that helped improve the manuscript. The research of J.S. was supported by funding through ESCAPE, that of S.D.A. by funding through ESCAPE and the UK Defence Evaluation and Research Agency (DERA/SESS/C21.10.2) awarded to Peter Burkill, Plymouth Marine Laboratory. Participation by P.G.V. was supported by grants from the US National Science Foundation (OCE-95-21086 and OCE-96-17884). The research also forms part of the CCMS-DYME programme of Plymouth Marine Laboratory.

\section{LITERATURE CITED}

Archer SD, Leakey RJG, Burkill PH, Sleigh M (1996) Microbial dynamics in coastal waters of East Antarctica: herbivory by heterotrophic dinoflagellates. Mar Ecol Prog Ser 139:239-255

Berges JA, Montagnes DJS, Hurd CL, Harrison PJ (1994) Fitting ecological and physiological data to rectangular hyperbole: a comparison of methods using Monte Carlo simulations. Mar Ecol Prog Ser 114:175-183

Cushing DH (1989) A difference in structure between ecosystems in strongly stratified waters and in those that are only weakly stratified. J Plankton Res 11:1-13

Edler L (1979) Recommendations for marine biological studies in the Baltic Sea: phytoplankton and chlorophyll. Baltic Marine Biologists WG9 Publication. The National Swedish Environmental Protection Board, Malmö

Edwards ES, Burkill PH, Stelfox CE (1999) Zooplankton herbivory in the Arabian Sea during and after the SW monsoon. Deep-Sea Res II 46:843-863

Eilertsen HChr, Taasen JP (1984) Investigations on the plankton community of Balsfjorden, northern Norway. The phytoplankton 1976-1978. Environmental factors, dynamics of growth, and primary production. Sarsia 69:1-16

Eilertsen HChr, Schei B, Taasen JP (1981a) Investigations on the plankton community of Balsfjorden, northern Norway. The phytoplankton 1976-1978. Abundance, species composition, and succession. Sarsia 66:129-142

Eilertsen HChr, Falk-Petersen S, Hopkins CCE, Tande K (1981b) Ecological investigations on the plankton community of Balsfjorden, northern Norway. Program for the project, study area, topography and physical environment. Sarsia 66:25-34
Fenchel T (1980) Suspension feeding in ciliated protozoa: feeding rates and their ecological significance. Microb Ecol 6:13-25

Fenchel T, Jonsson PR (1988) The functional biology of Strombidium sulcatum, a marine oligotrich ciliate (Ciliophora, Oligotrichina). Mar Ecol Prog Ser 48:1-15

Gallegos CL (1989) Microzooplankton grazing on phytoplankton in the Rhode River, Maryland: nonlinear feeding kinetics. Mar Ecol Prog Ser 57:23-33

Gifford DJ (1988) Impact of grazing by microzooplankton in the Northwest Arm of Halifax Harbour, Nova Scotia. Mar Ecol Prog Ser 47:249-258

Gifford DJ (1991) The protozoan-metazoan trophic link in pelagic ecosystems. J Protozool 38:81-86

Hansen BW, Jensen F (2000) Specific growth rates of protozooplankton in the marginal ice zone of the central Barents Sea during spring. J Mar Biol Assoc UK 80:37-44

Hansen B, Verity P, Falkenhaug T, Tande KS, Norrbin F (1994) On the trophic fate of Phaeocystis pouchetti (Harriot). V. Trophic relationships between Phaeocystis and zooplankton: an assessment of methods and size dependence. J Plankton Res 16:487-511

Hansen FC, Reckermann M, Klein Breteler WCM, Reigman R (1993) Phaeocystis blooming enhanced by copepod predation on protozoa: evidence from incubation experiments. Mar Ecol Prog Ser 102:51-57

Hegseth E, Svendsen H, Quillfeldt CHV (1995) Phytoplankton in fjords and coastal waters of northern Norway: environmental conditions and dynamics of the spring bloom. In: Skjodal HR, Hopkins C, Erikstad KE, Leinas HP (eds) Ecology of fjords and coastal waters. Elsevier Science, Amsterdam, p 45-72

Hopkins CCE, Tande KS, Grønvik S, Sargent JR (1984) Ecological investigations of the zooplankton community of Balsfjorden, northern Norway: an analysis of growth and overwintering tactics in relation to niche and environment in Metridia longa (Lubbock), Calanus finmarchicus (Gunnerus), Thysanoessa inermis (Krøyer) and T. raschii (M. Sars). J Exp Mar Biol Ecol 82:77-99

Keck A, Wassmann P (1996) Dynamics of particulate organic matter in the subarctic fjord Malangen, northern Norway. Seasonal and vertical patterns of sedimentation. Sarsia 80 : 259-276

Kivi K, Setälä O (1995) Simultaneous measurement of food particle selection and clearance rates of planktonic oligotrich ciliates (Ciliophora: Oligotrichina). Mar Ecol Prog Ser 119:125-137

Klein Breteler WCM, Schogt N, Baas M, Schouten S, Kraay GW (1999) Trophic upgrading of food quality by protozoans enhancing copepod growth: role of essential lipids. Mar Biol 135:191-198

Kroer N (1994) Relationships between biovolume and carbon and nitrogen content of bacterioplankton. FEMS Microbiol Ecol 13:217-224

Lancelot C, Keller MD, Rousseau V, Smith WO Jr, Mathot S (1998) Autecology of the marine haptophyte Phaeocystis sp. In: Anderson DM, Cembella AD, Hallegraeff GM (eds) Physiological ecology of harmful algal blooms. SpringerVerlag, Berlin, p 209-224

Landry MR (1993) Estimating rates of growth and grazing mortality of phytoplankton by the dilution method. In: Kemp PF, Sherr BF, Sherr EB, Cole JJ (eds) Handbook of methods in aquatic microbial ecology. Lewis, Boca Raton, p 715-722

Landry MR, Hassett RP (1982) Estimating the grazing impact of marine microzooplankton. Mar Biol 67:283-288

Legendre L (1990) The significance of microalgal blooms for 
fisheries and for the export of particulate organic carbon in oceans. J Plankton Res 12:681-699

Legendre L, Le Fèvre J (1989) Hydrodynamical singularities as controls of recycled versus export production in oceans. In: Berger WH, Smetacek VS, Wefer G (eds) Productivity of the ocean: present and past. Wiley, Chichester, p 49-63

Lutter S, Taasen JP, Hopkins CCE, Smetacek V (1989) Phytoplankton dynamics and sedimentation processes during spring and summer in Balsfjord, northern Norway. Polar Biol 10:113-124

MacManus GB, Okuba A (1991) On the use of surrogate food particles to measure protistan ingestion 36:613-617

Montagnes DJS, Lynn DH (1991) Taxonomy of choreotrichs, the major marine planktonic ciliates, with emphasis on the aloricate forms. Mar Microb Food Webs 5:59-74

Mullin MM, Stewart EF, Fuglister FJ (1975) Ingestion by planktonic grazers as a function of concentration of food. Limnol Oceanogr 20:259-262

Neuer S, Cowles TJ (1995) Comparative size-specific grazing rates in field populations of ciliates and dinoflagellates. Mar Ecol Prog Ser 125:259-267

Norrbin F (1994) Seasonal patterns in gonad maturation, sex ration and size in some small high-latitude copepods: implications for overwintering tactics. J Plankton Res 16: 115-131

Peperzak L (1993) Daily irradiance governs growth rate and colony formation of Phaeocystis (Prymnesiophyceae). J Plankton Res 15:809-821

Putland JN (2000) Microzooplankton herbivory and bacterivory in Newfoundland coastal waters during spring, summer and autumn. J Plankton Res 22:253-278

Reigman R, Noordeloos A, Cadée GC (1992) Phaeocystis blooms of the continental zones of the North Sea. Mar Biol 112:479-484

Reigstad M, Wassmann P (1996) Importance of advection for pelagic-benthic coupling in north Norwegian fjords. Sarsia 80:245-258

Riebesell U, Reigstad M, Wassmann P, Passow U, Noji T (1995) On the trophic fate of Phaeocystis pouchetii. VI. Significance of Phaeocystis-derived mucus for vertical flux. Neth J Sea Res 33:193-203

Rousseau V, Mathot S, Lancelot C (1990) Calculating carbon biomass of Phaeocystis sp. from the microscopic observations. Mar Biol 107:305-314

Rublee PA, Gallegos CL (1989) Use of fluorescently labeled algae (FLA) to estimate microzooplankton grazing. Mar Ecol Prog Ser 51:221-227

Sargent JR, Eilertsen HC, Falk-Petersen S, Taasen JP (1985) Carbon assimilation and lipid production in phytoplankton in Northern Norwegian fjords. Mar Biol 85:109-116

Sherr BF, Sherr EB, Fallon RD (1987) Use of monodispersed, fluorescently labeled bacteria to estimate in situ protozoan bacterivory. Appl Environ Microbiol 53:958-965

Sherr EB, Sherr BF, McDaniel J (1991) Clearance rates of $<6 \mu \mathrm{m}$ fluorescently labeled algae (FLA) by estuarine protozoa: potential grazing impact of flagellates and ciliates. Mar Ecol Prog Ser 69:81-92

Skjoldal HR, Hopkins C, Erikstad KE, Leinaas HP (1995) Ecology of fjords and coastal waters. Elsevier Science, Amsterdam

Stefels J (1997) ESCAPE field campaign in northern Norwegian fjords, April 7 to 25 1997. Second Annual Report, University of Groningen

Stoecker DK, Capuzzo JM (1990) Predation on protozoa: its importance to zooplankton. J Plankton Res 12:891-908

Stoll MHC, Rommets JW, De Baar HJW (1993) Effect of selected calculation routines and dissociation constants on

Editorial responsibility: John Dolan,

Edgewater, Maryland, USA the determination of total carbon dioxide in seawater Deep-Sea Res I 40:1307-1322

Straile D (1997) Gross growth efficiencies of protozoan and metazoan zooplankton and their dependence on food concentration, predator-prey weight ratio, and taxonomic group. Limnol Oceanogr 42:1375-1385

Strickland JDH, Parsons TR (1972) A practical handbook of seawater analysis. Bull Fish Res Board Can 167

Tande KS (1982) Ecological investigations on the zooplankton community of Balsfjorden, northern Norway: generation cycles and variations in body weight and body content of carbon and nitrogen related to overwintering and reproduction in the copepod Calanus finmarchicus (Gunnerus). J Exp Mar Biol Ecol 62:129-142

Tande KS, Grønvik S (1983) Ecological investigations on the zooplankton community in Balsfjorden, northern Norway: sex ratio and gonad maturation cycle in the copepod Metridia longa (Lubbock). J Exp Mar Biol Ecol 71:43-54

Tiselius P, Kuylenstierna M (1996) Growth and decline of a diatom spring bloom: phytoplankton species composition, formation of marine snow and the role of heterotrophic dinoflagellates. J Plankton Res 18:133-155

Velhuis MJW, Admiraal W (1987) Influence of phosphate depletion on the growth and colony formation of Phaeocystis pouchetii (Hariot) Lagerheim. Mar Biol 95:47-54

Verity PG (1991) Measurement and simulation of prey uptake by marine planktonic ciliates fed plastidic and aplastidic nanoplankton. Limnol Oceanogr 36:729-750

Verity PG, Sieracki ME (1993) Use of colour image analysis and epifluorescence microscopy to measure plankton biomass. In: Kemp PF, Sherr BF, Sherr EB, Cole JJ (eds) Handbook of methods in aquatic microbial ecology. Lewis, Boca Raton, p 327-338

Verity PG, Smetacek V (1996) Organism life cycle, predation and the structure of marine pelagic ecosystems. Mar Ecol Prog Ser 130:277-293

Verity PG, Vernet M (1992) Microzooplankton grazing, pigments and composition of plankton communities during the late spring in two Norwegian fjords. Sarsia 77:263-274

Verity PG, Robertson CY, Tronzo CR, Andrews MG, Nelson JR, Sieracki ME (1992) Relationship between cell volume and the carbon and nitrogen content of marine photosynthetic nanoplankton. Limnol Oceanogr 37:1434-1446

Verity PG, Stoecker DK, Sieracki ME, Nelson JR (1993) Grazing, growth and mortality of microzooplankton during the 1989 North Atlantic spring bloom at $47^{\circ} \mathrm{N}, 18^{\circ} \mathrm{W}$. DeepSea Res 40:1793-1814

Verity PG, Stoecker DK, Sieracki ME, Nelson JR (1996) Microzooplankton grazing of primary production at $140^{\circ} \mathrm{W}$ in the equatorial Pacific. Deep-Sea Res 43:1227-1255

Verity PG, Wassmann P, Ratkova TN, Andreassen IJ, Nordby E (1999) Seasonal patterns in composition and biomass of autotrophic and heterotrophic nano- and microplankton communities on the north Norwegian shelf. Sarsia 84: 265-278

Wassmann P (1991) Dynamics of primary production and sedimentation in shallow fjords and polls of western Norway. Oceanogr Mar Biol Annu Rev 29:87-154

Wassmann P, Svendsen H, Keck A, Reigstad M (1996) Selected aspects of the physical oceanography and particle fluxes in fjords of northern Norway. J Mar Syst 8:53-71

Weisse T, Scheffel-Möser U (1990) Growth and grazing loss in single-celled Phaeocystis sp. (Prymnesiophyceae). Mar Biol 106:153-158

Weisse T, Tande K, Verity P, Hansen F, Gieskes W (1994) The trophic significance of Phaeocystis blooms. J Mar Syst 5: $67-79$

Submitted: March 20, 2000; Accepted: May 19, 2000

Proofs received from author(s): July 11, 2000 